\title{
O QUE SIGNIFICA TRADUZIR FINNEGANS WAKE?
}

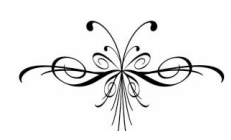

\section{LENITA RIMOLI ESTEVES}

Resumo: Este trabalho se dedica a uma análise de técnicas de escrita empregadas por Joyce em Finnegans Wake e de traduções de alguns excertos da obra feitas para o português. Mais que isso, pretende-se questionar o que significa, em que consiste, traduzir Finnegans wake. Com base na proposta teórica de Jean Allouch, que considera a tradução não com base na clássica oposição forma/sentido, mas num triplo, constituído por sentido / forma / não-sentido, ou seja, como parte de um conjunto complexo composto de três elementos (tradução, transcrição e transliteração), argumenta-se que, nos momentos em que não há efeito de significação, o tradutor se vê obrigado a criar um significado, para a partir dele realizar a tradução. Essa é a função básica dos paratextos, que em geral acompanham as traduções, aclarando, explicando e justificando a tradução.

Palavras-Chave: Finnegans Wake, James Joyce, tradução, Jean Allouch

\begin{abstract}
This paper examines the techniques James Joyce employed to write Finnegans Wake and proposes an analysis of some excerpts of this work translated into Portuguese. More than that, the aim is to raise an awkward question: what does translating Finnegans Wake mean or consist of? Based on the book Lettre pour Lettre, in which Jean Allouch proposes a different view of translation, not based on the classic opposition form / meaning, but as part of a complex composed of three elements (translation, transcription and transliteration), the argument is made that, at points where there is no signification effect, the translator is forced to create some meaning, so that from that meaning a translation becomes possible. This is the basic function of paratexts, which generally attend to the translation, illuminating, explaining and justifying it.
\end{abstract}

Keywords: Finnegans Wake, James Joyce, translation, Jean Allouch 
riverrun, past Eve and Adam's, from swerve of shore to bend of bay, brings us by a commodius vicus of recirculation back to Howth Castle and Environs.

Sir Tristram, violer d'amores, fr'over the short sea, had passencore rearrived from North Armorica on this side the scraggy isthmus of Europe Minor to wielderfight his penisolate war: nor had topsawyer's rocks by the stream Oconee exaggerated themselse to Laurens County's gorgios while they went doublin their mumper all the time: nor avoice from afire bellowsed mishe mishe to tauftauf thuartpeatrick: not yet, though venissoon after, had a kidscad buttended a bland old isaac: not yet, though all's fair in vanessy, were sosie sesthers wroth with twone nathandjoe. Rot a peck of pa's malt had Jhem or Shen brewed by arclight and rory end to the regginbrow was to be seen ringsome on the aquaface.

(Finnegans Wake, p. 3)

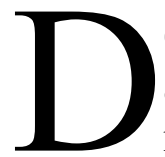

esde que começou a ser publicado, em trechos que ainda ainda seriam reelaborados, Finnegans Wake provocou reações adversas. Uma delas se apresenta de forma bastante pitoresca, numa carta que parodia o modo como Joyce escreve. Nessa carta, Vladimir Dixon chama o destinatário de James Joyce, Germ's Choice, e Shame's Voice. Alguns trechos: "I opened the window and in flew Enza", "You must not stink I am attempting to ridicul (de sac!) you or to be smart". "...[Am I] unable to combprehen that which is clear or is there really in your work some ass pecked which is Uncle Lear?" A carta termina assim: "Please, froggive my t'Emeritus and any inconvince that may have been caused by this litter" (DIXON, 1961, p. 193-4). Essa carta aparece num volume organizado por amigos e admiradores de Joyce, bem anterior à data da primeira publicação de Finnegans Wake, numa época em que fragmentos da obra (que tinha o nome provisório de Work in Progress) foram publicados em alguns periódicos.

O intuito desse volume, lançado pela primeira vez em 1929, dez anos antes de Finnegans Wake vir a público, era apresentar a nova obra de Joyce, que tanto estranhamento estava causando. Nele, vários autores argumentam a favor da inventividade de Joyce, do seu trabalho com a linguagem, da radicalidade de seu novo projeto. Os argumentos são vários. Robert Sage, por exemplo, afirma que

o espanto geral causado pelos fragmentos do Work in Progress de James Joyce que apareceram em Transition me parece uma indicação de que a maioria dos leitores não conseguiu perceber que as obras de 
Joyce, desde Dublinenses até o livro atual, formam um todo indivisível (SAGE, 1961, p. 149). ${ }^{1}$

Robert McAlmon, por sua vez, afirma que a literatura está mais presa à questão do significado do que o balé ou a música, por exemplo. Os críticos admitem que possa haver "arte pura" no balé ou na música, mas não na literatura (McALMON, 1961, p. 105). O autor diz também que Joyce percebera, havia anos, que o "subconsciente não pensa ou sente em idéias, mas em imagens", desejando certamente "quebrar a linguagem inflexível, dando-lhe maior flexibilidade e nuança”.

Dessa época até nossos dias, porém, o espanto não parece ter sido atenuado. Hoje em dia, pela Internet, ${ }^{2}$ podemos coletar opiniões tão adversas quanto aquelas expressas na época em que Finnegans Wake ainda era Work in Progress. Resenhas de "leitores comuns" ainda manifestam indignação, irritação e assombro diante da obra. Exemplos:

Não há enredo, o livro não explica nada, não descreve nada de forma coerente. Se o objetivo era capturar o estado onírico confuso e desorganizado de um escritor irlandês poliglota, bem, está tudo ali no papel. Mas é necessário um livro inteiro para isso?

"Out door, keel cooling vorsnevou". Essa frase poderia ser acrescentada a esse monte de babação e ninguém saberia que ela não foi escrita por Joyce... Um macaco e uma máquina de escrever poderiam ter escrito esse lixo "experimental". Não vejo por que essa "obra" é um clássico... Qualquer um poderia tê-la escrito.

É claro que nem todas as opiniões são negativas. No mesmo contexto, algumas resenhas enaltecem qualidades do livro:

Tudo bem, o livro é ilegível. Não é agradável e nos mostra definitivamente nossos limites em todas as categorias. Mas que poder terá um texto cujas primeiras cinco ou seis linhas poderiam ser o assunto de cem dissertações ou milhares de interpretações que fazem sentido? Experimente oferecer o primeiro parágrafo a um grupo de alunos e deixar que eles façam um brainstorming sobre o que poderia significar "riverrun...commodius vicus of recirculation... etc." e você vai ver e sentir isso.

Ou ainda:

\footnotetext{
${ }^{1}$ As traduções das citações, salvo indicado em contrário, são de minha autoria.

${ }_{2}^{2}$ Os comentários a seguir foram retirados do site da Amazon, distribuidora de livros pela Internet, num espaço reservado para que qualquer leitor possa dar sua opinião sobre livros que tenha lido. www.amazon.com; acessado em 26/10/2010.
} 
É fácil perceber por que a grande maioria das pessoas decidiria que tem outras prioridades. Respeito essa opinião. Mas, por favor, não atirem insultos em um livro que alguns de nós amamos. Sim, amamos. Ler FW é o ponto alto da minha vida. Emoção e estímulo: raiva, frustração, alegria, humor, deleite, até enfado. Relações profundas são difíceis. Elas machucam. E nos tornam mais vivos.

Nota-se, portanto, que o livro, desde que começou a vir a público, produz efeitos que acabam se polarizando em duas posições básicas. Uma admiração quase exaltada, alimentando produções acadêmicas que proliferam, ou, alternativamente, uma indignação profunda que não se pode calar. Talvez o motivo mais frequente dessa indignação seja uma impressão de ilegibilidade que o leitor tem na primeira vez que entra em contato com o livro. A propósito, Seamus Deane abre sua introdução à obra com as seguintes palavras:

A primeira coisa a dizer sobre Finnegans Wake é que a obra é, num sentido importante, ilegível. A fim de dedicar a esse livro a atenção que ele tão impertinente e infinitamente exige, o leitor deve abdicar da maioria das convenções sobre leitura e linguagem que o constituem como leitor (DEANE, 1992, p. vii).

Tentemos então examinar quais são as características que tornam tão difícil a leitura dessa obra. Uma das mais comentadas é a presença de termos de várias línguas, duas ou mais delas às vezes concentradas numa única palavra. Um exemplo é o termo wielderfight, transcrito no texto acima, que espelha o termo alemão "wiederfechten" ("lutar de novo"), juntando wieder ("novamente", "de novo") às palavras inglesas wield ("brandir", "empunhar", "dominar") e fight ("lutar").

Entre os estudiosos, acreditou-se, durante certa época, que no livro conviviam mais de quarenta línguas. Seamus Deane, em 1992, já apontava a existência de sessenta e cinco línguas, "que às vezes observam as convenções da gramática e sintaxe do inglês, mas com mais frequência as subvertem" (DEANE, 1992, p.xxviii).

Não deve causar espanto o fato de que, ao longo do tempo, os estudiosos atestem a presença de um número cada vez maior de línguas em Finnegans Wake. No exemplo citado anteriormente, da palavra wielderfight, poderíamos ter apenas wieder ("de novo", em alemão) e fight ("lutar", em inglês). Mas o acréscimo de um "l" traz outras associações, pela possibilidade de lermos também aí um wield inglês. Mas, se todas as línguas, ou um grande número delas, entrarem em jogo, que outras associações poderá trazer essa mesma palavra? $\mathrm{O}$ jogo não tem fim, se a regra básica permitir que virtualmente qualquer língua possa ser escutada nessa leitura. 
Em Finnegans Wake é preciso, mais do que em qualquer outro texto, tentar aplacar essa necessidade que todo leitor tem de "entender" o que está lendo. Mas, até que ponto isso é suportável? Se o leitor quiser entender esse texto de uma forma linear, fatalmente naufragará. Como observa Robert MacAlmon, no capítulo sobre Anna Livia Plurabelle, que é escrito para sugerir o fluxo do rio, não é importante o fato de Joyce ter se esforçado para buscar os nomes de muitos rios da terra, do céu e do inferno. O que importa é um efeito prazeroso que não necessariamente depende do significado (McCALMON, 1961, p.107).

Joyce cria, a todo momento, pontos de indecidibilidade, e nosso desejo de fechar a questão, de definir uma interpretação, de enclausurar num universo limitado as possibilidades associativas de uma passagem, fica em suspenso. A frase And he war, celebrizada pelo artigo de Derrida, "Duas Palavras por Joyce", é um bom exemplo disso. No momento em que Yaweh interrompe a construção da Torre de Babel e condena a humanidade à multiplicidade das línguas, Joyce escreve And he war. Derrida aponta aí o entrecruzamento de pelo menos duas línguas, o inglês e o alemão:

\begin{abstract}
War é um substantivo inglês, um verbo alemão, assemelha-se a um adjetivo nesta última língua (wahr) e o que há de verdadeiro nesta multiplicidade ocasiona o retorno, desde os atributos -- o verbo também é um atributo: o que ele é? aquele que foi -- em direção ao sujeito que se encontra, ele, he, dividido desde a origem (DERRIDA, 1992, p. 32).
\end{abstract}

Se o livro fosse escrito "estritamente" em inglês, a frase And he war seria inaceitável. Mas, como o jogo permite a invasão de outras línguas, podemos ler o war alemão como um was inglês, somado à idéia de guerra (perfeitamente cabível no contexto, já que Jahweh declara uma guerra aos homens) trazida pelo war em inglês. Então, o que foi mesmo que Joyce escreveu? Muitas coisas ao mesmo tempo. É como se tivéssemos várias mensagens se cruzando simultaneamente. Tudo ao mesmo tempo agora. Deus foi, fez-se presente, declarou uma guerra, e instituiu a verdade da multiplicidade das línguas. Tudo condensado em duas palavras. Esse efeito de condensação pode ser encontrado ao longo de todo o livro. São várias linearidades que se cruzam, várias vozes soando ao mesmo tempo, num concerto que, muitas vezes, deixa o leitor desconcertado.

Outra dificuldade apresentada pelo texto são as inúmeras alusões, quase sempre veladas, a uma gama enorme de universos, que incluem a Bíblia, toda a história da humanidade, a história da literatura e seus bastidores, a história da Irlanda, de Dublin e a própria história do autor. Mitos de várias culturas também se fazem presentes, entrelaçando-se à educação 
dos jesuítas, às relações familiares, a temas locais e universais, que podem ser invocados num mesmo momento e em várias línguas.

Para se ter uma idéia: segundo os estudiosos, no trecho de Finnegans Wake transcrito acima, em sosie sesthers wroth, temos uma alusão a três personagens bíblicas, Susana, Ester e Rute, ${ }^{3}$ envolvidas pelas paixões de homens mais velhos, um tema recorrente em Finnegans Wake, aludido também em vanessy [Vanessa que, juntamente com Stella, mantinha uma espécie de triângulo amoroso com Jonathan Swift, cujo nome de batismo aparece na forma anagramática Nathanjoe, termo que é precedido por twone, dois em um, que, por sua vez, alude ao mesmo triângulo: Not yet, though all's fair in vanessy, were sosie sesthers wroth with twone Nathanjoe.${ }^{4}$ Para um leitor que desconheça esses nomes e as tramas em que foram envolvidos, o efeito será de grande estranhamento.

Uma das formas de driblar esse estranhamento é consultar livros que "explicam" Finnegans Wake. Essa via indireta de abordagem, a partir dos textos dos estudiosos, coloca, no entanto, uma questão. O que esses

\footnotetext{
${ }^{3}$ As três histórias, do Antigo Testamento, resumem-se assim: Susana era uma jovem belíssima que despertou a paixão de dois velhos. Estes tentaram assediá-la escondendose num jardim reservado no qual a moça se banhava. Profecia de Daniel, cap. 13. (Em Finnegans Wake é um homem de mais idade - H.C.E - que espia duas moças num jardim quando estas estão urinando). Ester é uma donzela muito bonita que, dentre várias, é escolhida pelo rei Assuero (ou Ataxerxes) como esposa, ocupando o lugar da antiga rainha, Vasti, pois esta havia desobedecido às ordens do rei. O pai adotivo de Ester, Mardoqueu, tem um sonho profético em que uma pequena fonte cresce até se tornar um rio, transforma-se em luz e em sol, e derrama águas "em grandíssima abundância". Ester salva o povo judeu da crueldade dos persas. Livro de Ester. (Em Finnegans Wake, Anna Livia Plurabelle, A. L. P. , é associada às águas do Liffey, rio que atravessa Dublin. A. L. P. promove a redenção de seu marido, H. C. E., que é acusado de atos indecentes e ilícitos). Rute, jovem viúva, casa-se com Booz, homem idoso e rico, e concebe um filho seu, Obed, continuando a linhagem da família que estava ameaçada. Booz é parente do falecido marido de Rute. Por direito, os parentes mais próximos de um falecido poderiam apossar-se de seus bens e de suas mulheres. O fato de Booz, em idade avançada, poder gerar um filho, é considerado uma dádiva de Deus. Livro de Rute.

4 Essas interpretações, entre outras, encontram-se em vários autores, entre eles Anthony Burgess (1966) e Augusto e Haroldo de Campos (1971). Paulo Vizioli oferece uma explicação mais detalhada. Jonathan Swift, deão de S. Patrício, tem vínculos afetivos com duas jovens, Esther Johnson e Esther Vanhomrigh, mais conhecidas como Stella e Vanessa, "que despertaram em Swift uma afeição de contornos algo inesperados num homem de sua idade e vocação. Sua correspondência com elas está contida em Journal to Stella, escrito em linguagem simples e carinhosa, que Joyce frequentemente parodia em Finnegans Wake, com termos inconsequentes como Pepette, Pipetta, ppt e outros. Embora duas pessoas, representam elas uma só tentação, que é a que Isabel exerce sobre H. C. E". (VIZIOLI, 1991, p. 106, nota 92). H.C.E. é uma das figurações do personagem central. Isabel é a filha de H.C.E.
} 
estudiosos fazem é uma espécie de tradução de Finnegans Wake. ${ }^{5}$ Eles vão indicando as chaves dos enigmas que se enfileiram ao longo do livro. E, a partir dessas chaves, construindo um enredo, caracterizando os personagens. Vão dando, por assim dizer, um corpo, uma consistência a esse texto ilegível. Vão abrindo caminhos para que se leia o ilegível. Mas não estaria Joyce, com essa obra, propondo uma outra concepção de leitura, que não passe pelo "entendimento", pela apreensão de um enredo, ou pelo menos que dê uma importância secundária a esses processos? E se os estudiosos fazem essa espécie de tradução, não estariam eles traindo (oh, irremediável sina!) a proposta do autor que os inspira? Traição ou não, essas chaves se fazem necessárias, pelo menos inicialmente. Como afirma Vizioli:

A verdade é que ninguém consegue apreender muito do romance sem o amparo das sinopses e exegeses elaboradas pelos críticos e pesquisadores. Mas, por outro lado, também é verdade que poucos serão capazes de apreciar, no melhor sentido da fruição estética, o derradeiro trabalho de Joyce, se ficarem atentos demais a toda a densa floresta de sinais e placas que foi plantada para a sua orientação (VIZIOLI, 1991, p. 121).

Roland McHugh indica que a maioria dos trabalhos sobre Finnegans Wake, que seguem, de uma maneira ou de outra, A Skeleton Key to Finnegans Wake, de Campbell e Robinson, lançado pela primeira vez em 1944, produzem uma narrativa legível e coerente a partir de fragmentos do texto. Mas, infelizmente, afirma McHugh, o texto de Finnegans Wake, quando tratado dessa maneira, deixa de possuir uma atração ou um interesse real. Nas palavras do autor, a substituição do texto de Finnegans Wake por uma "tradução" em forma de narrativa contínua tem o efeito de desviar o leitor de um confronto direto. (McHUGH, 1991, p. v).

Cria-se, portanto, um impasse. Se, por um lado, é praticamente impossível dispensar o auxílio do trabalho dos pesquisadores numa primeira abordagem, por outro lado esse auxílio pode se transformar num estorvo à fruição estética da obra. É como se, de início, necessitássemos desse auxílio, até sermos, de alguma forma, capturados pelo movimento da obra, por esse torvelinho de trocadilhos, por essa caudalosa metamorfose ondulante.

Insisto em expressões como "de início" e "numa primeira abordagem" porque, após várias tentativas, o livro já não assusta tanto. É como se estivéssemos aprendendo a ler de novo, e cada tentativa é menos frustrante, ficando o leitor cada vez mais enredado nessas letras que, a princípio não revelam claramente um enredo. Como não se desaprende a

\footnotetext{
${ }^{5}$ Neste trabalho, com base na proposta de Jean Allouch, a tradução será abordada como uma operação regida pelo sentido. Os estudiosos estariam, portanto, dando sentido ao ilegível.
} 
ler, não há retorno nessa aventura. Apesar de aparentemente não haver um fim determinado desse aprendizado, existe algum tipo de evolução. Tratase, no caso, de conhecer algumas regras do jogo. E uma delas é retornar, retornar sempre. Recorrer, riverrun. E dar ouvidos à recorrência. O livro exige que se retorne a ele, retorno que será recompensado por novas descobertas e novos desafios. É muito comum, nessa experiência, ler uma passagem já lida como se fosse a primeira vez. Outra regra exige (e não, como poderíamos pensar, apenas permite) que se esteja atento a uma outra escuta, que o leitor não se deixe enclausurar no desejo de unidade, de univocidade. É necessário se entregar aos jogos simbólicos, aos jogos de letras que o texto impõe. Submeter-se ao texto, sem tentar domesticá-lo.

Ultrapassado, ou melhor, aceito um primeiro obstáculo de opacidade quase total, e estando o leitor disposto a continuar na sua empreitada e munido de coragem suficiente para isso, ele logo perceberá que o livro realmente impõe uma outra forma de leitura, que não seja centrada num enredo, na continuidade de uma história. A graça do livro não está numa sequência de fatos. Os fatos, aliás, se repetem, transformados ou camuflados que sejam; a recorrência é uma das características mais marcantes desse commodius vicus of recirculation. A graça está, então, no modo como se dá essa recorrência, sempre de uma forma nova, bland old.

Mas, voltando às indignadas queixas de leitores comuns contemporâneos, transcritas anteriormente: será mesmo que um macaco e uma máquina de escrever poderiam ter feito coisa melhor? Será que qualquer um poderia ter escrito essa obra? Seria a originalidade imputada ao último trabalho de Joyce um mito, ou o fruto de uma cegueira coletiva?

De que seja possível tentar imitar Joyce, não há dúvidas. A própria carta de Dixon o atesta. Nos pequenos fragmentos apresentados, nota-se que Dixon se vale, duas vezes, de uma técnica que poderíamos chamar de desvio, ou deslizamento. "I opened the window and in flew Enza". "You must not stink I am attempting to ridicul (de sac!) you". Temos aqui uma sequência que, acrescida de uma palavra, desvia do caminho que consideraríamos natural em termos sintáticos. Poder-se-ia esperar, depois de "I opened the window and in flew", algo como "the breeze", por exemplo. Mas o que Dixon faz, a partir do final da sequência, é acrescentar um outro termo que perverte o caminho que estaríamos antecipando. Mesmo que Enza fosse uma entidade mítica, uma deusa dos ventos, por exemplo, a sequência não deixaria de ecoar, ao mesmo tempo, "influenza", que quebra um efeito de sentido antecipado.

Não se pode negar, porém, que, para quem puder ouvir o eco de "influenza", cria-se um efeito de riso. O mesmo ocorre com o segundo fragmento, em que "de sac" desvia a sequência. É um desvio inesperado, 
que não tem sentido, mas provoca o riso. Joyce se vale da mesma técnica quando escreve, por exemplo, bottom sawyer ( $F W, 173.29-30)$.

Outro procedimento de que se vale Dixon, que imita as técnicas de Joyce, é fazer jogos homofônicos. Em "which is clear or is there really in your work some ass pecked which is Uncle Lear" há um jogo entre "clear" e "unclear", trazido por "Uncle Lear". Além, é claro, da menção a bicadas no traseiro de alguém em "ass pecked", que ecoa "aspect". É por meio desses jogos homofônicos, que aparecem na escrita joyciana numa profusão vertiginosa, que o autor consegue a condensação a que nos referimos antes.

Portanto, é possível imitar Joyce, mas será que qualquer um poderia ter escrito Finnegans Wake? Jogos homofônicos, todos fazemos, até sem querer, e Freud escreveu longamente sobre isso. Mas escrever uma obra assim tão extensa, tão descolada de um enredo ou de uma sequência de fatos, tão cheia desses jogos homofônicos, tão aberta a inúmeras possibilidades associativas, será que qualquer um poderia tê-lo feito? Pelo menos até o momento, ninguém mais o fez. E, se alguém tentou fazê-lo, o fruto de seu trabalho certamente apontará para Finnegans Wake. A radicalidade dessa obra é tal que, mesmo num escrito anterior, podemos identificar momentos "joycianos". É o que afirma Derrida, quando diz que a obra de Joyce acaba englobando toda a literatura, anterior e posterior a ela:

Nossa admiração por Joyce não deveria ter limites, nem a dívida em relação ao acontecimento singular de sua obra. É sem dúvida melhor falar aqui de acontecimento do que de obra, sujeito ou autor. [...] $\mathrm{O}$ acontecimento apresenta aqui uma intriga e uma envergadura tais que doravante não temos outra saída: ser em memória dele. Não apenas por ele excedidos, quer se saiba disto ou não, mas por ele obrigados, forçados a nos medir segundo esse excesso (DERRIDA, 1992, 19-20, grifos do autor).

Derrida insiste no fato de que, desse "acontecimento" que é a obra joyciana, somos a todo momento expulsos, sendo também, paradoxalmente, tragados por ele:

É com este sentimento, poderia dizer com este ressentimento, que devo estar lendo Joyce há muito tempo. Seria eu, por acaso, o único? Richard Ellmann citou recentemente as confissões de muitos escritores, críticos, artistas, todos admiradores ou próximos de Joyce, e que disseram qualquer coisa sobre esse mesmo mal-estar. Mas não sei se podemos dizer "eu leio Joyce", como acabei de fazer. Naturalmente, só podemos ler Joyce, quer saibamos disto ou não. É a sua força. Mas os enunciados do tipo "eu leio Joyce", "leiam Joyce", "você já leu Joyce?" sempre me pareceram cômicos, irresistivelmente. (p. 21, grifo do autor). 
Joyce, e especificamente Finnegans Wake, constituem um acontecimento na literatura. Mas também é inegável que muitos não consideram Finnegans Wake uma obra literária. Para alguns, o livro é de uma arte radical, extrema; para outros, trata-se de uma escrita que se assemelha à produção de um louco. De qualquer forma, é praticamente impossível ignorar Joyce no panorama da literatura ocidental. Podemos apreciar ou não sua obra, dedicar anos de nossa vida ao estudo de seus experimentalismos ou então fechar o livro para nunca mais abri-lo. Mas parece impossível ter tentado ler Finnegans Wake e não recordar, de alguma forma, essa experiência.

Este trabalho se dedica a uma análise da escrita de Joyce em Finnegans Wake e de traduções de alguns excertos da obra feitas para o português. Mais que isso, pretende-se questionar o que significa traduzir Finnegans Wake. Com base na proposta teórica de Jean Allouch, que considera a tradução não com base na clássica oposição forma/sentido, mas num triplo, constituído por sentido/forma/não-sentido, ou seja, como parte de um conjunto complexo composto de três elementos (tradução, transcrição e transliteração), argumenta-se que, nos momentos em que não há efeito de significação, o tradutor se vê obrigado a criar um significado, para a partir dele realizar a tradução. Essa é a função básica dos paratextos, que em geral acompanham as traduções, aclarando, explicando e justificando a tradução.

\section{A técnica de escrita de Joyce contraposta aos conceitos de tra- dução, transcrição e transliteração}

Segundo Jean Allouch, "escrever se chama transcrever quando o escrito é regulado pelo som, traduzir quando se baseia no sentido e transliterar quando é regido pela letra" (ALLOUCH, 1994, p. 14). Em seu livro Letra a Letra, Allouch procura, por diversos caminhos, definir a psicanálise como uma "clínica do escrito", sendo a transliteração o procedimento que deve reger essa clínica. Dado que, na abordagem de Allouch, as três operações não são isoláveis (trata-se, isso sim, de uma questão de prevalência, em cada caso, de uma sobre as outras duas), este trabalho buscará verificar que consequências essa proposta pode ter para o campo da tradução.

Da mesma forma que Derrida aponta para um certo aspecto risível da pergunta: "Você já leu Joyce?", podemos achar engraçada a pergunta: “Alguém já traduziu Finnegans Wake?”. Traduziu de que língua para que outra? Se, como afirmam alguns autores, Joyce fragmentou, 
quebrou, desmantelou a língua inglesa, o tradutor terá também que compor um texto desmantelando sua língua.

Antes de uma análise das traduções, é interessante pensarmos no que Joyce realiza em termos de técnica de escrita. Quebrar palavras e compô-las em novos conjuntos, pondo em jogo várias cadeias significantes simultaneamente, parece ser a tônica dessa técnica. Mas ela tem várias vertentes, vários modos de se fazer.

Num confronto com as três operações de escrita propostas por Allouch - tradução, transcrição e transliteração - com qual delas essa técnica se assemelha? Vários dados apontam para uma escrita regida pelo som. Afirmaram alguns que o texto joyciano, e especificamente Finnegans Wake, deve ser lido em voz alta. A fruição deve muito à melodia, à cadência, ao aspecto musical do texto. Além disso, Joyce brinca muito com sons parecidos. Como aponta Paulo Vizioli, uma das técnicas empregadas pelo autor em Finnegans Wake é a paródia. Tomam-se frases conhecidas, de domínio público, para deturpá-las num efeito cômico.

A frase final da persignação,

In the name of the Father and of the Son and of the Holy Ghost. Amen",

transforma-se em

In the name of the former, and of the latter and of their holocaust. Amen" (FW, 419-10-11).

Uma outra referência religiosa:

Maria, full of grease, the load is with me,

que ecoa

Hail, Mary, full of grace, the Lord is with thee. (FW, 214.18-19)

Podem ocorrer também paródias de pequenos textos menos conhecidos, como um anúncio de uma peça teatral, que de:

Newlly billed for each weekday performance. Sunday matinees. By arrangement, children's hours, expurgated,

transforma-se em: 
Newlly billed for each wickeday perfurmance. Somndoze massinees. By arraignment, childream's hour, expercatered (FW, 219. 4-6).6

O trecho "transformado", como aponta Paulo Vizioli, faz dos dias da semana (weekdays) dias ruins (wickedays). As matinês de domingo (Sunday matinees), passam a ser espetáculos soporíferos para as massas (somndoze massinees/ somn - "sono", doze "cochilar", mass, "massas") (VIZIOLI, 1991, p. 95).

Também são constantes, no livro, as paródias literárias:

Where it is nobler in the main to supper than the boys and errors of outrager's virtue,

parodia os versos de Shakespeare em Hamlet:

Whether "tis nobler in the mind to suffer

The slings and arrows of outrageous fortune. ${ }^{7}$

O sofrimento passa a ser uma refeição (suffer/supper); dardos e arremessos transformam-se em meninos e erros [boys and errors, que, por sua vez, ecoam duas palavras que geralmente aparecem juntas, bow and arrow, arco e flecha]; o fado adverso [outrageous fortune] vem transformado em virtude daquele que excede [outrager virtue]. Essa técnica poderia ser descrita como uma reconstrução de frases conhecidas por meio da substituição de alguns fonemas por outros semelhantes, tendo por base a assonância (week por wicke, arrows por errors, e assim por diante). Essa substituição ao mesmo tempo deturpa e enriquece o sentido da frase conhecida, já que, como a frase a que se alude, ela continua a "refletir", num jogo, a frase deturpada.

De qualquer forma pode-se dizer que, nessas passagens, a assonância rege a técnica de Joyce, partindo da alusão. No caso dessas paródias, a alusão, remetendo a uma frase conhecida, cria esse efeito de "deturpação do sentido". É possível afirmar, portanto, que a transcrição rege a técnica das paródias, mas também entra em jogo a tradução, pois não deixa de ser mantido um certo vínculo semântico com a frase aludida.

Quando esse processo de paródias se dá de uma língua para outra, o sentido é às vezes totalmente ignorado, reinando, soberana, a transcrição. Em seus programas humorísticos, certas estações de rádio costumam

\footnotetext{
${ }^{6}$ Valho-me da tradução de Paulo Vizioli para o primeiro trecho: "Apresentação reprogramada para cada dia da semana. Matinês dominicais. Por acordo prévio, horários infantis, expurgados" (VIZIOLI, 1991, p. 95).

${ }^{7}$ Segundo e terceiro versos do monólogo "To be or not to be, that is the question". Hamlet, ato III, cena 1).
} 
fazer paródias de canções conhecidas, "traduzindo-as" para o português sem nenhuma preocupação com o sentido, mantendo-se apenas um certo encadeamento de fonemas. Nesse caso, a alusão se faz apenas a uma determinada cadeia sonora. Uma canção com o refrão: "Please don't go, you're the only angel I know" transforma-se, nesse processo, em "Fiz dois gol, pena que o juiz anulou".

Mas para rir de uma paródia é preciso ter uma mínima familiaridade com o contexto onde ela se faz. É preciso conhecer a citação, para reconhecê-la depois de transformada. Joyce, em sua erudição, muitas vezes nos deixa no escuro. A frase da persignação é fácil de reconhecer, mas outras referências literárias talvez exijam maior conhecimento.

Joyce se vale, no entanto, de outras tantas técnicas para escrever Finnegans Wake. Numa de suas inúmeras alfinetadas que dá na psicanálise, Joyce escreve:

old Sykos who have done our unsmiling bit on 'alices, when they were yung and easily freudened (FW, 115.21-23).

Segundo William York Tindall, (1969, p. 106), nesse trecho, um personagem tenta empreender uma abordagem psicanalítica da literatura. A junção de palavras não contíguas numa frase [Sykos... on 'alices] nos fornece a chave de um enigma já insinuado nas referências a Freud e Jung [yung e freudened]. Ainda segundo Tindall, alices nos traz um Lewis Carroll "psicanalisado" por William Empson que, em sua análise da Alice do País das Maravilhas, aponta o fato de Carroll ser um velho [old Sykos] encantado por meninas [on alices].

Aqui se pode observar uma técnica diferente, regida pela homofonia. Na teorização de Allouch, a assonância é o procedimento que rege a transcrição, ao passo que a homofonia rege a transliteração. O efeito produzido aqui difere do obtido nas paródias.

Nos exemplos das paródias, podemos dizer que a técnica é presidida pelo som. Por meio de substituições dos sons da cadeia conhecida, produz-se uma deturpação, que gera um efeito cômico. No último exemplo, uma sequência de fonemas acaba criando uma "cadeia truncada", que, cruzando-se com a cadeia enunciada, acaba produzindo um efeito chistoso. Sykos on 'alices nos traz "psychoanalysis", mas as duas cadeias se cruzam num único ponto, que, apesar disso, não deixa de ser sustentado por Jung e freudened. Nas paródias, as cadeias parecem permanecer num paralelo que é sustentado em toda a sua extensão, a paródia como que refletindo uma imagem deturpada da cadeia original (às vezes refletindo som e sentido, outras vezes apenas a cadeia sonora). O efeito do segundo procedimento é mais sutil, e exige que o leitor saiba colocar os fragmentos certos nas posições certas, o que exige dele uma outra escuta, uma escuta mais articulada em termos simbólicos, pois é uma espécie de 
decifração. O efeito de criação de novos sentidos produzido nessa transliteração não nos traz apenas um "reflexo deturpado" de um sentido do discurso corrente. Produz-se algo novo, inusitado, e o equívoco nos traz a produção de uma mensagem nova, que não está em paralelo com uma outra cadeia, mas cruza com ela, irrompe nela, num procedimento que se assemelha à formação de um chiste, no sentido freudiano do termo (Cf. FREUD, 1905).

Justamente por isso, é possível dizer que Joyce translitera quando articula dois fragmentos significantes, Sykos on'alices, que não por um suposto conteúdo, mas sim, por homofonia, remetem a um outro significante [psychoanalysis], que traz junto consigo uma outra cadeia.

De qualquer forma, Joyce, em sua inventividade, é capaz de transliterar num sentido mais "cabal" ou "primário". Se transliteração significa, em primeira instância, "mudar letras de lugar", Joyce também translitera desse modo, com frequência.

Já na primeira página do livro, aparece o termo Nathanjoe, que seria uma espécie de anagrama de Jonathan. Posteriormente, num capítulo que gira em torno de uma carta [letter], temos a sequência: thence your pristopher polombos, hence our Kat Kresbyterian $(F W, 120.2)$. Um pouco adiante, a frase: how hard a thing it is to mpe mporn a gentlerman ( $F W$, 120. 9). Tindall nos informa que a substituição de b por $\mathbf{m p}$ indica que Joyce tinha conhecimento do grego moderno, onde $\mathbf{m p}$ tem a função de $\mathbf{b}$ (TINDALL, 1969, p. 108). Esses enigmas criados por Joyce trazem pistas. No caso de Nathanjoe, um "contexto" pode indicá-las, em sosie sesthers e em twone (Swift e suas duas Esteres). Em pristopher polombos, as palavras que vêm logo em seguida, Kat Kresbyterians, nos indicam uma possibilidade de substituição. Em mpe mporn, o início da frase já nos daria uma indicação (how hard a thing it is to $e$ orn a gentlerman), mas também existe uma referência ao grego poucas linhas depois. ${ }^{8}$

Um trecho da obra, analisado por Magalaner e Kain, pode nos fornecer uma passagem em que os jogos de letras são abundantes:

...The new world presses. Where de old conk cruised now croons the yunk. Exeunc throw a darras Kram of Llawnroc, ye gink guy, kirked into yord. Enterest attawonder Wehpen, luftcat revol, fairescapading in his natsirt. Tuesy tumbles. And mild aunt Liza is as loose as her neese. Fulfest withim inbrace behent. As gent would deem oncontinent. So mulct per wenche is Elsker woed. Ne hath his thrysting. Fin. (FW, 387.36-388.1-6)

Há nesse trecho palavras invertidas, escritas de trás para a frente:

\footnotetext{
${ }^{8}$ those superciliouslooking crisscrossed Greek ees awkwardlike perched there and here out of date like sick owls hawked back to Athens (FW, 120. 19-20).
} 


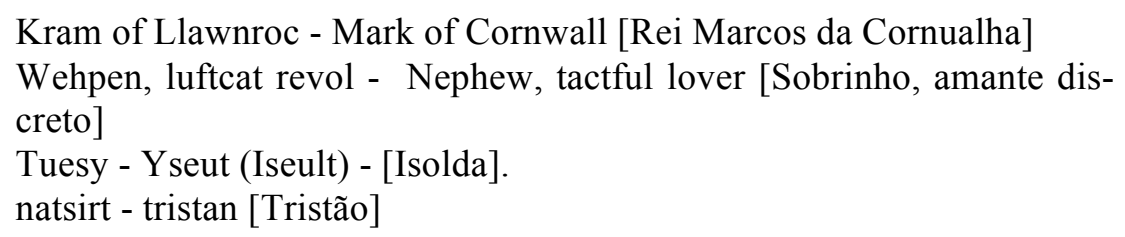

Invertendo a posição das letras, colocando-as de trás para a frente, temos então os personagens da história de Tristão e Isolda. ${ }^{9} \mathrm{O}$ tema da paixão de um homem mais velho por uma jovem reaparece, no amor do Rei Marcos por Isolda. A substituição do velho pelo novo [The new world presses] é evocada pela troca de posições, o jovem sobrinho assumindo o lugar do tio. Em sua análise, Magalaner e Kain (1956, p. 234) se perguntam sobre o motivo dessas inversões. Estaria Joyce simplesmente buscando fascinar os viciados em enigmas ou ostentando seu desdém pela comunicação direta da linguagem dos homens?

Os autores encontram uma justificativa para os "fogos-de-artifício verbais" de Joyce na própria lenda. Devido às circunstâncias perigosas que enfrenta, Tristão se vê forçado a ocultar sua verdadeira identidade sob um pseudônimo. Invariavelmente, adota anagramas do seu próprio nome, chamando-se com mais frequência de Tantris (ou Temtriss).

Além das palavras "perfeitamente ao contrário", temos também outro tipo de jogo de letras, em forma anagramática: gink - king [rei], que os autores informam que, em gíria, quer dizer "tolo". E juntamente com essas ocorrências, as palavras-valise, que tanto notabilizaram Joyce.

Fairescapading, por exemplo, traz o sentido de "fazer uma escapada" (pela associação com o verbo francês faire [fazer] e também com escape [escapar] em inglês). Como colocam os autores (1956, p. 235), o mito vem "modernizado", e Tristão e Isolda se encontram aqui não num navio, mas em motéis baratos, o que evoca fire-escape [saída de incêndio], pela qual o jovem herói empreende uma escapada repentina e discreta (tactful).

Roland McHugh (1961, p. 388) traz um outro elemento de que se pode valer a interpretação desse fairescapading: No julgamento de Par-

${ }^{9}$ Tristão e Isolda é uma lenda, provavelmente de origem celta, que se tornou um dos mais populares temas de narrativas medievais. Tristão, príncipe de um reino escocês, fica órfão em tenra idade. Raptado por piratas, é recolhido pelo tio, Marcos, rei da Cornualha. Após diversas aventuras, realiza uma viagem à Irlanda, a fim de pedir a mão de Isolda para seu tio. Na viagem de retorno, bebem por engano um filtro mágico de amor. Ligados por paixão eterna, vivem um romance secreto. Descobertos pelo Rei Marcos, são obrigados a se separar. Ferido num combate, Tristão agoniza; Isolda vem para revêlo, mas chega tarde e morre sobre o corpo inanimado do amante. As mais antigas versões da lenda datam do século XII. Richard Wagner compôs uma ópera homônima, de grande sucesso. 
nell, ${ }^{10}$ evidências mal-interpretadas sugeriram que ele havia utilizado uma saída de incêndio para deixar o quarto de sua amante, Mrs. O'Shea, quando foi surpreendido.

Voltando ao estudo de Magalaner e Kain: A frase exeunc throw a darras ecoa exeunt through an arras, que nos faz lembrar de indicações cênicas, e particularmente do modo como o jovem Hamlet faz Polônio desaparecer de cena - e do mundo - mediante uma ação rápida. ${ }^{11} \mathrm{~A}$ indicação cênica deformada (de exeunt para exeunc) compõe a saída com o(s) tio(s) (Mark ou Kram): exeunt e uncles ["saem" e "tios"]. As associações vão bem mais longe, embora os autores digam, num determinado ponto, que encerram a análise do trecho "deixando de lado várias associações [...] por medo de sobrecarregar o leitor com detalhes" (MAGALANER e KAIN, 1956, p. 235-6).

Há outros trechos de Finnegans Wake que não apresentam, no entanto, esse tipo de "complicação". Veja-se o trecho a seguir, em que há poucas "novidades" em termos de experimentação linguística. O trecho é confuso devido a uma profusão de nomes e ações que vão se enredando e provocando vertigens no leitor. Poderíamos dizer que, nesse caso, o que rege a escrita é mesmo o sentido, embora ele "escape" em virtude da proliferação de informações.

O trecho emerge, já no final do livro, estabelecendo uma diferença com o que vem antes e o que vem depois. Comparado a outras passagens, é de uma clareza surpreendente. Os pais (HCE-ALP) estão recolhi-

${ }^{10}$ Charles Stewart Parnell foi um líder político irlandês, que lutou contra a dominação britânica. Como nos explica Paulo Vizioli: “...eleito em 1875, [Parnell] soube lutar pela autonomia política da nação ("Home Rule") com eficientes táticas de obstrução no Parlamento Britânico. O sucesso estava à vista, e a expectativa era grande. Foi então que irrompeu a crise que alterou por algum tempo os destinos do país e marcou indelevelmente o menino James Joyce e muitos outros de sua geração: descobriu-se que Parnell mantinha um caso de amor com uma certa senhora O'Shea, esposa de um seu companheiro de partido; armou-se de pronto um escândalo público, com o apoio do clero católico (Parnell era protestante); acusou-se o deputado de envolvimento em dois assassinatos políticos ocorridos no Phoenix Park, o parque da cidade; e ele não foi reeleito. Rejeitado, caluniado e frustrado, pouco depois morria o grande líder." (VIZIOLI, 1991, p. 19).

${ }^{11}$ Na peça de Shakespeare, Polônio é o camareiro-chefe e homem de confiança da rainha, além de ser pai de Ofélia, por quem Hamlet está apaixonado. Ao longo da peça, Hamlet começa a simular uma loucura, despertando o espanto dos que o rodeiam. $\mathrm{Na}$ cena IV do terceiro ato, a rainha chama o filho para que conversem, sendo que Polônio se esconde por detrás de reposteiro (arras) para ouvir a conversa. Hamlet entra, começa a acusar a mãe por ter traído e matado seu marido, e então desconfia da presença de mais alguém no cômodo. Hamlet desembainha sua espada e acaba matando Polônio através do reposteiro [through the arras]. A analogia entre a lenda de Tristão e Isolda e a história de Hamlet se sustenta no fato de este último ter matado e tirado de cena o pai de sua jovem amada. Da mesma forma, Tristão tira de cena o tio, para ficar com Isolda. 
dos em seus aposentos; um dos três filhos tem o sono perturbado e chora. Os pais vão olhá-lo. No momento em que a criança já dorme tranquila de novo, é como se toda a torpeza da humanidade fosse revelada ali. Como colocam Campbell e Robinson, "praticamente sem aviso algum, uma espiada relativamente inocente em um quarto descortina um atoleiro de indescritível decadência" (CAMPBELL e ROBINSON, 1944, p. 269). Os autores continuam com seu comentário: "o aparentemente saudável oceano de amor paterno se deteriora em um mar doentio povoado de monstros de incesto e perversão". Nessa espécie de revelação, os desejos mais ligeiros e furtivos da humanidade aparecem como se tivessem sido levados a uma plena realização.

Mas o que contrasta diretamente com esse universo pantanoso e perverso é a linguagem em que ele é construído. Joyce se vale de uma espécie de linguagem legalista, utilizada em tribunais. A "naturalidade" com a qual tantas torpezas desfilam diante dos nossos olhos acaba criando um efeito cômico, misturado ao horror. Como observam Campbell e Robinson, ficamos horrorizados ao constatarmos que esses assuntos podem ser discutidos na "enfadonha terminologia da experiência legal cotidiana" (CAMPBELL e ROBINSON, 1944, p. 269). Anthony Burgess observa que, após a criança ter sido acalmada, o casal pode voltar ao seu aposento, mas antes disso somos presenteados com "uma sinistra e gélida fantasia de perversão sexual que resume nossa era aviltada". Ainda segundo o autor, a linguagem legalista e desperta, após tanto sonhar, é como uma "ducha de água fria" (BURGESS, 1966, p. 242).

Ainda sobre o contraste entre a torpeza do assunto tratado e o caráter burocrático da linguagem empregada, William Y. Tindall comenta:

Tudo o que esteve latente no complexo familiar vem à luz aqui, como se viesse dos divãs de Viena, com toda a ajuda de Grécia. A clareza desse documento, emergindo da escuridão onírica que o rodeia, garante o efeito. Recuando horrorizados[...], nós rimos...(TINDALL, 1969, p. 292).

Tindall recorre ao conceito de "grotesco" para caracterizar esse trecho. Valendo-se de uma definição de Ruskin, ele afirma que qualificase de "grotesca" uma espécie de arte que combina o aterrador com o engraçado. Vejamos então de que se trata. Convém alertar o leitor de que, neste trecho, Honuphrius corresponde a HCE, e Anita a ALP.

The procurator Interrogarius Mealterum presends us this proposer.

Honuphrius is a concupiscent exservicemajor who makes dishonest propositions to all. He is considered to have committed, invoking droit d'oireller, simple infidelities with Felicia, a virgin, and to be practising for unnatural coits with Eugenius and Jeremias, two or three philadelphians. Honophrius, Felicia, Eugenius and Jeremias are consanguine- 
ous to the lowest degree. Anita the wife of Honophrius, has been told by her tirewoman, Fortissa, that Honuphrius has blasphemously confessed under voluntary chastisement that he has instructed his slave, Mauritius, to urge Magravius, a commercial, emulous of Honuphrius, to solicit the chastity of Anita. Anita is informed by some illegitimate children of Fortissa with Mauritius (the supposition is Ware's) that Gillia, the schismatical wife of Magravius, is visited clandestinely by Barnabas, the advocate of Honuphrius, an immoral person who has been corrupted by Jeremias. Gillia (a cooler bland, D'Alton insists) ex equo with Poppea, Arancita, Clara, Marinuzza, Indra and Iodina, has been tenderly debauched (in Halliday's view) by Honuphrius, and Magravius knows from spies that Anita has formerly committed double sacrilege with Michael, vulgo Cerularius, a perpetual curate, who wishes to seduce Eugenius. Magravius threatens to have Anita molested by Sulla, an orthodox savage (and leader of a band of twelve mercenaries, the Sullivani), who desires do procure Felicia for Gregorius, Leo, Vitellius and Macdugalius, four excavators, if she will not yield to him and also deceive Honuphrius by rendering conjugal duty when demanded. Anita who claims to have discoreved incestuous temptations from Jeremias and Eugenius would yield to the lewdness of Honuphrius to appease the savagery of Sulla and the mercernariness of the twelve Sullivani, and (as Gilbert at first suggested), to save the virginity of Felicia for Magravius when converted by Michael after the death of Gillia, but she fears that, by allowing his marital rights she may cause reprehensible conduct between Eugenius and Jeremias. Michael, who has formerly debauched Anita, dispenses her from yielding to Honuphrius who pretends publicly to possess his conjunct in thirtynine several manners (turpiter! affirm ex cathedris Gerontes Cambronses) for carnal hygiene whenever he has rendered himself impotent to consummate by subdolence. (FW, p. 572. 21- 573. 23).12

Esse trecho, embora seja confuso, não é exatamente um desafio para um tradutor. Isso porque, aqui, é bem mais fácil atribuir um sentido; a sintaxe não "desliza", não é interrompida por algum termo que não esperaríamos, como acontece com alguns trechos já analisados aqui. Em termos gerais, encontramos nessa obra mais cadeias sintáticas "deslizantes" do que "comportadas", mais articulações de termos onde a materialidade significante é primordial do que o contrário, mais frases enigmáticas do que enunciados do discurso corrente. Passemos então a uma análise de traduções de alguns trechos dessa obra, verificando quais foram as dificuldades encontradas e as soluções buscadas.

\footnotetext{
${ }^{12}$ Note-se uma alternância entre as formas Honuphrius e Honophrius. Não se sabe se terá sido um erro de impressão (que teria ocorrido mais de uma vez) ou uma variação intencional.
} 


\section{Wake}

\section{Comentários sobre alguns trechos de traduções de Finnegans}

Em primeiro lugar, começando finalmente a abordar as traduções de trechos de Finnegans Wake, é conveniente retomar certos conceitos e pressupostos que foram adotados neste trabalho.

Partindo da proposta de Allouch e da constatação de que as três operações de escrita (tradução, transcrição e transliteração) não existem isoladamente, pudemos verificar que certos trechos de Finnegans Wake resistem mais à tradução que outros. Nos pontos em que impera um compromisso com os sentidos, as dificuldades são menores, pois trata-se aí de substituir uma ordenação sintática do inglês por uma outra que gere, em português, um efeito de significação semelhante. É óbvio que a "correspondência" nunca será perfeita pois, mesmo em se tratando de efeitos de significação, as línguas são singulares em seus mecanismos simbólicos.

Nos pontos em que rege a assonância, nas paródias por exemplo, a situação se complica um pouco, pois o tradutor deverá guardar uma semelhança não só com efeitos de significação, mas também com efeitos sonoros. Como cada língua tem suas particularidades fonêmicas, a operação terá, no caso das paródias, menos compromisso com os sentidos proporcionados pela deturpação da cadeia na língua original (a deturpação da frase conhecida), do que com uma semelhança sonora entre uma cadeia que a ela corresponda na língua-alvo e uma cadeia "deturpadora" dessa primeira cadeia. É o que se observa na tradução da paródia: Lord help you, Maria, full of grease, the load is with me, em que os tradutores se valem da sequência "Lave Maria, cheia de graxa, o suor é conosco" (CAMPOS e CAMPOS, 1971, p. 61). O importante aqui é que o leitor identifique a sequência traduzida com a oração em português. $\mathrm{O}$ efeito a ser trabalhado é o da assonância. O compromisso é mais com a cadeia sonora que com a significação.

Já quando numa cadeia se dá um efeito de criação de novos sentidos, um efeito poético ou chistoso, é muito difícil que o compromisso com a materialidade significante se mantenha juntamente com o caráter inusitado do novo sentido produzido. Esse efeito, apontando justamente para a singularidade das línguas, representa para o tradutor um ponto de impossibilidade. O tradutor terá de escolher entre um ou outro compromisso.

Muitas vezes apela-se para as notas de rodapé, explicando o efeito obtido na língua-fonte. Caso o tradutor não deseje tomar esse caminho, terá então de substituir a cadeia por uma outra que produza um efeito semelhante. Muitos julgam que isso não constitui um verdadeiro "problema", já que, nesses casos, a homofonia e o equívoco por ela trazido é que são importantes, como um acontecimento. É o que argumenta Arthur Nes- 
trovski, quando afirma que o que geralmente se considera como o grande impedimento para a tradução de Finnegans Wake, ou seja, o uso extensivo de trocadilhos e palavras-valise, não é de fato uma fonte de ansiedade tão grande assim:

Não é difícil sobrecarregar uma língua com outras línguas; o que é difícil é transformar o movimento dessa língua em direção a si mesma. Quanto aos trocadilhos, a perda ocasional de um elemento em um ponto da tradução pode ser compensada por seu aparecimento em algum outro ponto adequado, e é característico do texto de Joyce haver sempre algum outro ponto adequado. As questões técnicas, entretanto, não podem ser consideradas separadamente das aporias interpretativas exercidas de forma implacável por Joyce. O tradutor, cujo papel tradicionalmente tem sido não dizer nada, mas sim transferir o que foi dito pelo autor para um domínio mais puramente lingüístico, depara-se aqui com as dificuldades da enunciação, que lhe são impostas pelo caráter aberto da fonte. (NESTROVSKI, 2010, p. 90)13.

Portanto, a leitura do texto de Finnegans Wake poderá exigir, em diferentes pontos, um compromisso maior com a transcrição, com a tradução ou com a transliteração, alternadamente. Ao empreender sua tarefa, o tradutor, no caso de uma dominância da transcrição, precisará conhecer os elementos a que o texto alude. Para tanto, recorrerá, sem dúvida, aos textos explicativos, aos estudos sobre a obra, às referências sobre o autor, sua cultura, seus interesses. O que não é, de modo algum, um empreendimento fácil. Mas digamos que não é impossível.

Todo esse conhecimento será também necessário quando o compromisso principal for com a significação ou com o acontecimento que constitui a criação de novos sentidos. E a técnica modalizar-se-á segundo a operação que rege cada trecho. No entanto, o trabalho, que pretende ser de tradução, nunca poderá abandonar um compromisso, maior ou menor, com a significação. Se nessa obra, como afirma Nestrovski, o tradutor se vê a cada momento enfrentando "as dificuldades da enunciação", criadas pelo "caráter aberto da obra", seu problema crucial será a necessidade de, de uma forma ou outra, domesticar esse caráter aberto da obra, atribuindo-lhe uma significação, ou várias significações simultâneas que sejam, para depois poder recriá-las na língua-alvo.

Se Finnegans Wake nos impõe a cada passo o indecidível, como "reproduzir" seus mecanismos de escrita e ainda honrar um certo compromisso com a significação? Não é à toa que os estudiosos se referem

${ }^{13}$ NESTROVSKI, Arthur. Mercius (de seu mesmo): Notas sobre uma tradução brasileira de Finnegans Wake. Tradução: Carolina Paganine. In Scientia Traductionis, James Joyce e Tradução, n.8. Florianópolis, 2010. Disponível em: http://www.periodicos.ufsc.br/index.php/scientia/issue/current (N. do E.) 
aos textos explicativos e às exegeses como "traduções" da obra. Por outro lado, se alguém pensasse em "reproduzir" a técnica joyciana, sem nenhum compromisso com possíveis significações, o resultado seria outro. Uma simples "imitação" das técnicas empregadas por Joyce não garantiria que o resultado do trabalho fosse uma tradução. O texto a seguir, de Caetano Veloso, parece comprovar a afirmação. Notam-se aí algumas das técnicas empregadas por Joyce. Mas, em hipótese alguma, pode-se dizer que isso seja uma tradução de Finnegans Wake.

Cremúsculo. O sol, a só, despe de si, digo, depede-se, desce pé ante pele, descalço, dá-se e sobe, digo, sob, ou melhor, sobre as bandas cremoças das mulheres alfíssimas do hemisferno nhorte. Kolinas sonrisam no horizonte. Mastros desde senham-se no ocidonte. Acapulcos e havaís tampouco. Tranquislidade. Noite. Não há dúvidas: é chegada a hera dos maiares desgrossos (VELOSO, 1979, p. 333).

Em contrapartida, há uma outra questão a ser considerada, tratando-se de Finnegans Wake. Traduzir essa obra, levando em conta apenas o que seria um "enredo", um "conteúdo”, também parece impossível. Qual seria esse conteúdo? Como afirmam Magalaner e Kain (1956, p. 219), "é praticamente impossível falar sobre o enredo de Finnegans Wake. A obra deve ser lida". Afinal de contas, que história é essa? Mesmo os estudiosos que tentam dar conta de um enredo, vão apresentando esse enredo ao leitor em camadas, superpondo uns elementos a outros.

Poderíamos começar assim: Um homem, dono de um bar, sonha em sua cama depois de um dia de trabalho estafante. No sonho desse homem estarão elementos de um desejo incestuoso seu pela própria filha. Esse homem tem dois filhos gêmeos. Um é escritor, artista, pouco dado a assuntos pragmáticos e mundanos. O outro é seu oposto. Uma pessoa inescrupulosa e aproveitadora. Chega a assumir a autoria de textos do irmão para ganhar popularidade e a estima pública. A mulher daquele que sonha é a figura que poderá redimi-lo de suas culpas.

Mas, em mais de seiscentas páginas, só acontece isso? Essa pergunta poderia ser feita por qualquer pessoa que ouvisse a explicação acima. A ela os estudiosos responderiam que se, de uma certa maneira, nada mais acontece na história, nela são lembradas inúmeras outras histórias, que têm uma relação com essa primeira história. Essas outras narrativas, mitos ou fatos históricos não são de fato narrados, mas sim aludidos de uma forma bastante tortuosa e enigmática. Sua presença na obra se justifica por associações de ideias. Histórias diversas, de datas diferentes e até mesmo de culturas distintas têm em comum algum tema. Esses temas se repetem, criando um movimento circular que nos sugere que o mundo é composto de eras que se sucedem. Ao final da última era inicia-se novamente a primeira, e assim infinitamente. Essa circularidade é confirmada 
pela própria frase inicial do livro, que se abre com uma palavra em letra minúscula, riverrun, e é, na verdade, a continuação da última frase do texto.

Alguns dos "temas recorrentes" aludidos: a substituição do velho pelo novo, as gerações mais novas ocupando o lugar das mais velhas, homens maduros que alimentam paixões ilícitas por mulheres muito mais jovens, a culpa. Esses temas e essas narrativas paralelas foram organizados pela primeira vez num livro pioneiro, lançado em 1944, de autoria de Joseph Campbell e Henry Morton Robinson. Todos os estudiosos citados neste trabalho, sem exceção, citam essa obra e baseiam-se nela. Anthony Burgess a classifica como uma obra fundamental na difícil tarefa de decifrar Finnegans Wake (1966, p. 65). Um dos capítulos desse livro aparece traduzido por Augusto de Campos no Panaroma do Finnegans Wake (MAGALANAER e KAIN, 1971). William York Tindall, apesar de admitir ter-se valido desse livro, afirma que, quando escrevia o seu, se afastou de Cambpell e Robinson. Diz também que, reabrindo agora $A$ Skeleton Key to Finnegans Wake, percebe que os autores divergem dele em algumas interpretações (TINDALL, 1969, p. 25).

Quem consulta os estudiosos chega à conclusão de que existe um certo consenso nas interpretações. Pode-se dizer que existe uma interpretação "básica" de Finnegans Wake, a partir da qual traduções foram feitas. E não é de surpreender que todas as traduções com as quais tive contato, para o português e algumas outras línguas, jamais dispensam um texto introdutório, uma explicação, que funciona também como uma justificativa para as traduções. Conclui-se daí que Finnegans Wake não é, em geral, um livro que possa ser lido sem esse auxílio. Uma escrita tão aberta aos jogos de palavras, tão cheia de alusões e enigmas, pode, teoricamente, significar quase qualquer coisa. A presença de línguas diferentes do inglês traz inúmeras possibilidades, das quais muitas vezes nem nos damos conta.

Para de fato empreender a tradução, o tradutor deve escolher, mas, nessa escrita enigmática, vê-se obrigado a justificar sua escolha. E essa escolha é uma espécie de fechamento das possibilidades associativas do texto. Sem esse fechamento, sem uma espécie de definição de qual é o sentido do texto, a tradução é impossível. Mas sempre fica o impasse, as outras possibilidades, o que poderia ter sido. O texto traduzido não deixa de ser uma domesticação do original. Mas, como já vimos, Finnegans Wake é uma obra que, já na língua de partida (e afinal de contas, qual será essa língua?) pede para ser domesticada, explicada, desdobrada.

Passo agora a uma análise apenas da primeira página de Finnegans Wake como traduzida pelos irmãos Campos em Panaroma de Finnegans Wake.. Como será possível verificar, a escrita joyciana é tão in- 
trincada que a análise se estende numa medida que muitos considerarão demasiada. Justamente por isso, não analiso aqui outras traduções do mesmo trecho para o português (nem o trabalho do prof. Donaldo Schüler, que sem dúvida é uma obra de fôlego e merece toda a nossa admiração e nossa atenção). A análise proposta a seguir tem o intuito principal de justificar a afirmação de que traduzir Finnegans Wake é necessariamente domesticar o texto, reduzindo suas possibilidades associativas. Mas isso não quer dizer que as traduções sejam textos menos importantes ou significativos. Não há outro caminho para traduzir essa obra. O Panaroma do Finnegans Wake foi publicado em 1971 numa edição revisada e ampliada. Dezesseis fragmentos são apresentados em tradução, ao lado do texto original. Depois de apresentados os dezesseis fragmentos, segue um texto explicativo referente a cada um deles, justificando as escolhas feitas pelos tradutores.

riverrun, past Eve and Adam's, from swerve of shore to bend of bay, brings us by a commodius vicus of recirculation back to Howth Castle and Environs.

riocorrente, depois de Eva e Adão, do desvio da praia à dobra da baía, devolve-nos por um commodius vicus de recirculação devolta a Howth Castle Ecercanias.

Como já foi dito anteriormente, o livro começa no meio de uma frase, cujo início está na última página, na última linha. Pode-se constatar que esse início tem uma estrutura sintática bem-definida, que não traz muitos problemas para o tradutor: atribuindo-se a riverrun a função de sujeito, teríamos a seguinte estrutura:

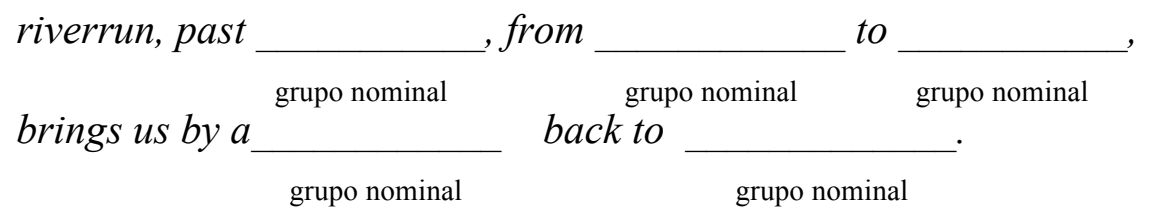

que é reproduzida em português num paralelo quase perfeito:

devolve-nos por um $\underset{\text { grupo nominal }}{\text { grupo nominal }} d a_{\text {grupo nominal }}^{\stackrel{a}{\text { grupo nominal }}}$.


Ao termo past só podemos atribuir o valor de preposição, já que temos Eve and Adam's logo em seguida, certamente um grupo nominal. Em inglês, a sequência past Eve and Adam's parece trazer mais fortemente a idéia de "além de Eve and Adam's", principalmente por causa do apóstrofo, que sugere um lugar. Poderíamos pensar em "Eve and Adam's time", mas, nesse caso, ficaria faltando o substantivo. Quando temos um grupo nominal seguido apenas de apóstrofo, é de se esperar que o tal grupo nominal se refira a um lugar. Uma consulta mais detalhada aos estudiosos nos informa que existe uma Eve and Adam's Church às margens do rio Liffey (McHUGH, 1991, p.1) Em português, a sequência "depois de Eva e Adão", sugere mais tempo que lugar ("após a era de Eva e Adão"), justamente porque "depois" é um advérbio, que poderia indicar tanto lugar quanto tempo, mas, dado que temos logo em seguida Eva e Adão, fica difícil supor que se trate de um local.

Nesse primeiro parágrafo, como indica o texto que comenta a tradução, estão o princípio masculino e o feminino, Adão e Eva, às margens do rio Liffey, em Dublin. Como na escrita de Joyce o improvável sempre acontece, não fica descartado o jogo entre os personagens Eva e Adão e a localidade, "Eve and Adam's Church", que nos permite interpretar esse past também como um "after". A tradução acabou privilegiando o sentido temporal com "depois". O problema (eis a singularidade das línguas em ação) é que não existe em português uma palavra que tenha o exato valor que past assume em inglês nesse contexto. O leitor em português só irá associar Eva e Adão a um lugar se consultar os textos explicativos. Mas os textos explicativos nunca deixam de acompanhar as traduções.

Ainda na mesma sequência, os termos from, to, e to sugerem que os espaços em branco devem ser ocupados por grupos nominais que indiquem lugares. By nos faz esperar um termo que indique modo ou instrumento. Em inglês, o único termo que sugere um retorno é back em brings us...back to. Já em português cria-se uma espécie de pleonasmo em devolve-nos...devolta.

Também está presente nesse parágrafo a idéia de circularidade (talvez por isso o "acréscimo" de devolta), com a teoria de Vico sobre as eras da humanidade que se sucedem infinitamente, formando um círculo vicioso (commodius vicus of recirculation). Vicus significa "rua", e alude ao mesmo tempo a Vico e à Vico Road, de Dublin. Commodius, faz alusão ao imperador romano Commodus, da fase decadente de Roma (daí a terminação em dius, que, em latim, pode significar "há muito tempo"). Howth Castle é uma localidade de Dublin e as palavras, unidas a Environs, formam juntas as iniciais do personagem H. C. E., que deverá substituir Finnegan, ao mesmo tempo o gigante mítico irlandês (Finn MacCool) e o pedreiro (Tim Finnegan) que caiu de uma escada quando construía 
um muro e morreu, para depois despertar em seu velório com o cheiro do uísque que lhe foi borrifado pelos presentes. Temos então a queda (de Roma, do pedreiro, do gigante mítico, de Adão e Eva e, com eles, da humanidade) e a ressurreição, garantida pela circularidade das fases por que passa a humanidade.

$\mathrm{Na}$ tradução, as palavras estrangeiras ao inglês permanecem estrangeiras em português (commodius vicus, do latim). A conjunção dos fonemas em português cria uma cacofonia em Eva e Adão; riocorrente é um termo que nos traz a idéia de rio e fluxo que temos em riverrun. No entanto, em português há mais fonemas consonantais, dois deles oclusivos, que diminuem o efeito de fluxo sugerido por riverrun em inglês. José Antônio Arantes, tradutor de Burgess para o português, opta por correrrio, que mantém o número de sílabas e elimina quase totalmente os sons oclusivos (cf. BURGESS, 1971, p. 212). Donaldo Schüler, autor da tradução integral da obra para o português, opta por rolarrioanna, fazendo uma referência também a Anna Lívia, personagem que simboliza o rio Liffey.

O texto prossegue ainda com uma sintaxe razoavelmente regular, e a tradução a segue em paralelo:

Sir Tristram, violer d'amores, fr'over the short sea, had passencore rearrived from North Armorica on this side the scraggy isthmus of Europe Minor to wielderfight his penisolate war:

Sir Tristrão, violista d'amores, através o mar breve, não tinha ainda revoltado de Norte Armórica a este lado do áspero istmo da Europa Menor para loucomover sua guerra penisolada:

Montando o "esqueleto sintático" da sequência, atribuiríamos os seguintes valores aos termos inusitados:

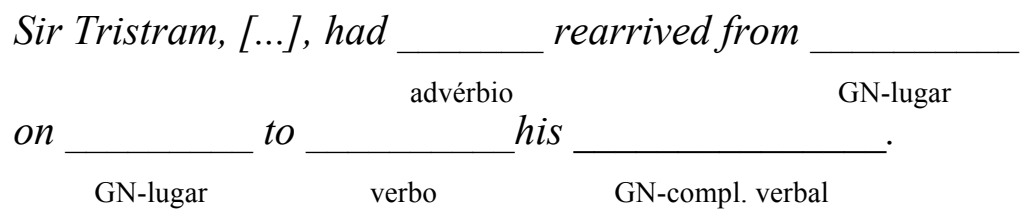

Em português, temos:

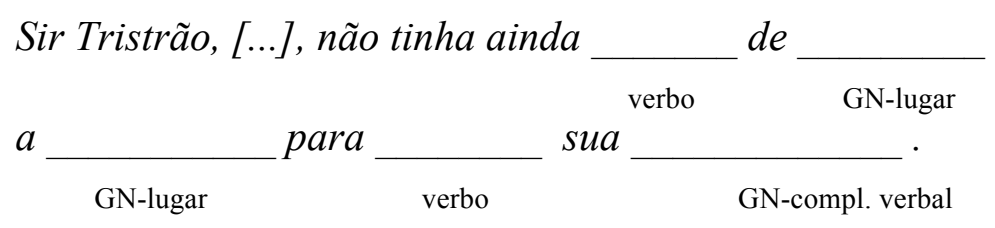


Entre had e rearrived, só poderia vir um advérbio. O termo passencore vem como um "ainda não" em francês. Mas mesmo que o leitor não perceba esse termo como a contribuição de um vocábulo estrangeiro, só se poderia esperar aí um advérbio que indicasse tempo. Como, na sequência, são enumeradas várias coisas que não tinham acontecido, existe uma tendência a considerar esse passencore como uma negativa. A tradução abre mão do termo estrangeiro nesse ponto, utilizando apenas o "não tinha ainda" e o efeito de estranhamento se perde. Em compensação, revoltado é uma palavra-valise, muito mais estranha ao português que rearrived para o inglês. Nessa solução pode-se observar o que aponta Nestrovski quando diz que a perda ocasional em um ponto pode ser compensada por um efeito semelhante (no caso aqui, o estranhamento) em outro ponto adequado.

Nesse segundo parágrafo, como coloca o tradutor Augusto de Campos em seu texto explicativo, temos Tristram, que seria uma referência a Almeric Tristram, fundador de Howth Castle, ${ }^{14}$ fundido à figura de Tristão. Tristão conquista Isolda, Tristram conquista a Irlanda. Tanto no original quanto na tradução, as preposições nos fazem antecipar nomes de lugares (from-on; $d e-a$ ). North Armorica, além de lembrar "América do Norte", também se refere à Bretanha do Norte. Europe Minor refere-se provavelmente à própria Irlanda. Wielderfight é uma junção de prefixo alemão, wieder que significa "de novo", "outra vez", com fight, "lutar" em inglês. Mas há também o acréscimo de um "l", que pode sugerir, como já foi dito anteriormente, o verbo inglês "wield", que significa, além de "brandir" ou "empunhar" uma arma, também "deter o poder".

Antonio Arantes parece fazer a mesma associação, pois traduz a frase assim: rebrandir sua guerra penisolada (Cf. BURGESS, 1971, p. 213). Já Renato Pompeu faz outra associação, com o termo inglês wild ("louco", "selvagem), parecendo aí concordar com Campos, que escreve "loucomover". Entretanto, Arantes não incorpora essa ideia da loucura nesse ponto específico de sua tradução, com "para voltar a lutar sua guerra penisolada". Donaldo Schüler escolhe "para o violento conflito de penisoldada guerra" (SCHÜLER, 1999, p.3), procedimento que traz a abolição do verbo, mas por outro lado remete a Isolda, em "penisoldada". Como se vê, dependendo da interpretação eleita pelo tradutor, as cadeias significantes tomam rumos diferentes. Augusto de Campos escolhe a frase loucomover sua guerra penisolada. Não se encontra aqui o wieder alemão e nem a idéia que o termo transmite, apesar de essa mesma idéia poder ser

\footnotetext{
${ }^{14}$ Como indica Renato Pompeu, Sir Almeric Tristram foi um dos cavaleiros ingleses que, no século XII d. C., iniciou a conquista da Irlanda, tendo se tornado o primeiro conde de Howth, ou seja, passou a residir no Castelo de Howth que aparece no primeiro parágrafo (POMPEU, 1988a, p. 25-6).
} 
encontrada em outros pontos, como por exemplo em revoltado, palavravalise que traz a idéia de retorno pelo prefixo re- e também a idéia de guerra com revolta-. Mais uma vez, um termo estrangeiro (wieder) não aparece como estrangeiro na tradução. Em penisolate war, temos uma referência óbvia ao órgão sexual masculino, mas a palavra também ecoa "península". Guerra penisolada é uma saída interessante, recuperando os dois sentidos.

Sobre as frases intercaladas ainda não analisadas, violer d'amores, fr'over the short sea, note-se que embora o tradutor não comente nada sobre violer d'amores, temos aí a fusão do italiano com o francês. Viola d'amore é, em italiano, um instrumento musical. Violer, em francês significa "violar". Temos então a sugestão de um trovador que é também um violador. A solução de Campos, com violista d'amores, parece enfatizar mais a idéia do trovador, e menos a do violador.

Note-se o efeito criado por através o mar breve em português, ecoando "atravessa o mar breve", o que se justifica pelo fato de tanto Tristram quanto Tristão terem atravessado o mar para chegar à Irlanda. Essa formação não segue as regras sintáticas do português. Através exige uma preposição de, que não aparece no texto. Por outro lado, também em inglês, mas não no ponto correspondente, falta uma preposição: on this side (of) the scraggy isthmus. Na vertente de um estranhamento da estrutura sintática, a tradução reproduz um efeito do original.

Prosseguindo na sequência, temos:

nor had topsawyer's rocks by the stream Oconee exaggerated themselse to Laurens County's gorgios while they went doublin their mumper all the time:

nem tinham os calhões do altomsawyerrador pelo rio Oconee sexagerado aos gorgetos de Laurens County enquanto eles iam dublando os bebêbados todo o tempo:

Verificando a estrutura sintática:

nor had $\underset{\text { grupo nominal }}{\text { while they__ }}$ their_meio
verbo

E em português:

\begin{tabular}{|c|c|c|c|c|}
\hline nem tinham os & $s$ & & sexagerado & aos \\
\hline & grupo nominal & GN-meio & & GN-compl. verbal \\
\hline & verbo & upo nomina & & \\
\hline
\end{tabular}


Tanto nor quanto nem criam a necessidade de uma negativa anterior, que só poderá ser localizada em passencore no original (supondo-se que essa palavra ecoa o francês pas encore), e, em português, poderá ser atribuída mais facilmente a não tinha ainda. Algumas informações sobre referências no trecho:

Stream Oconee é um rio em cujas margens, como explica Augusto de Campos, fica a cidade americana de Dublin, homônima da Dublin irlandesa. Essa Dublin americana fica em Laurens County, na Geórgia. O fundador dessa cidade foi Peter Sawyer. Por isso aparecem no trecho os termos Laurens County, gorgios (ecoando "Geórgia") e topsawyer (que pode sugerir uma associação com Tom Sawyer).

No primeiro espaço em branco, onde podemos esperar um grupo nominal, temos, em inglês, Topsawyer's rocks, que traz os dois "Sawyers". Rocks pode sugerir uma idéia de "pedra", "pedregulho", mas, como indicam os tradutores, ${ }^{15}$ é um termo de gíria que pode significar "testículos" ou dinheiro. Daí a opção por os calhões (palavra-valise que traz calhau = "pedra", "seixo" e colhões = termo chulo para "testículos") do altomsawyerrador.

Se em inglês temos topsawyer-, que ecoa "Tom Sawyer" e ao mesmo tempo nos sugere "alto", em português foi necessário o acréscimo do fragmento significante al- para que um efeito de significação semelhante se produzisse. Roland McHugh nos esclarece que "Topsawyer's Rock" é uma formação rochosa do tal rio Oconee (McHUGH, 1991, p. 1). Em inglês, "Tom Sawyer" está apenas sugerido, por uma assonância, ao passo que em português o nome está inteiro no termo, explícito: altomsawyerrador. Os tradutores também se preocuparam em explorar o termo "sawyer" ("serrador") como um substantivo comum, com a terminação -errador. A tentativa de concentrar tantas possibilidades semânticas trazidas por um único grupo nominal acabou criando, em português, um termo bem mais longo e pesado.

No segundo espaço em branco se dá a simples substituição de stream por rio. Os tradutores explicam que Oconee, além de ser o nome de um rio às margens da Dublin americana, também evoca a exclamação irlandesa de pena ou lamentação, "ochone". Logo após temos o verbo exaggerated, seguido de themselse, que aglutina "themselves" e "else". A solução dos tradutores foi sexagerado, que além de aglutinar o termo reflexivo a "exagerar", ecoa também "sexagenário", que indicaria um dos

15 Todas as referências ao texto explicativo dos tradutores para esse trecho estão no $P a$ naroma do Finnegans Wake, pp. 81-82. 
polos da oposição velho/novo ${ }^{16}$. Essa associação é um "acréscimo" da tradução, pois não fica possibilitada pelo texto em inglês.

While they went doubling é uma sequência bastante sugestiva, trazendo as duas cidades homônimas (Dublin) e o próprio processo de duplicação. Aliás, nesse parágrafo como um todo, termos ou fragmentos que indicam duplicidade e repetição são uma constante: wieder- ("de novo"), doublin, mishe mishe, tauftauf, twone, sosie sesthers. A duplicação também é uma constante no livro. No sonho de H. C. E., o objeto de seu desejo aparece como duas moças no parque Fênix. Swift está às voltas com duas Esteres. Os filhos de H. C. E. são gêmeos, duas lavadeiras fofocam no capítulo VIII do livro I, e assim por diante.

No parágrafo correspondente em português, ecoam também vários termos ou fragmentos que sugerem o tema da duplicação: revoltado, dublando, bebêbados, mishe mishe, tauftauf, sesters sósias, uníduo, papamalte.

Em português, enquanto eles iam dublando os bebêbados aproveita a assonância com doubling e traz a idéia de duplicação, reforçada por bebêbados, que traz também o outro pólo da oposição velho/novo com bebe-. Mumper é uma gíria que significa "cigano", "vagabundo", daí a associação com "bêbados" (Cf. McHUGH, 1991, p. 1).

Em seu texto explicativo sobre a tradução, Augusto de Campos cita a interpretação de Campbell e Robinson num trecho que transcrevo abaixo:

Campbell e Robinson assim "traduzem" este trecho: "um filho bem sucedido de HCE emigra do leste para o oeste, como seu pai fizera antes. Estabelecendo-se na América, tem uma larga descendência e lhe augura grande prosperidade." (CAMPOS e CAMPOS, 1971, p. 82).

Não deve ser à toa que o tradutor usa a palavra "traduzem" nesse trecho. A frase comentada, que vai de nor had... até ... all the time, mesmo com as alusões esclarecidas, continua intrincada e difícil. Campos apresenta então a "tradução" de Campbell e Robinson, ou seja, o sentido que eles atribuíram ao trecho. A frase correspondente em português também não esclarece muita coisa. Pelos conectivos, not yet, nor, juntamente com os verbos no passado had passencore rearrived, exaggerated, bellowsed temos a sugestão de uma época muito antiga, em que não tinha ocorrido uma série de coisas. Também podemos notar a oposição velho/novo e o tema da duplicação. Mas a "tradução" de Campbell e Robinson é "amarrada", "arrumada" demais, simplificando ao extremo toda a complexidade do parágrafo. O próprio título de seu livro "Chave-Mestra para Finnegans

\footnotetext{
16 Associação que ganha mais força quando ficamos sabendo que Isac era sexagenário quando nasceram seus filhos gêmeos, Esaú e Jacó.
} 
Wake" já indica uma certa pretensão de domesticação, como se ele pudesse abrir todas as portas que compõem esse enigma.

Prosseguindo:

nor avoice from afire bellowsed mishe mishe to tauftauf thuartpeatrick:

nem avoz de umachama bramugira mishe mishe a um tauftauf tuespatruísquio:

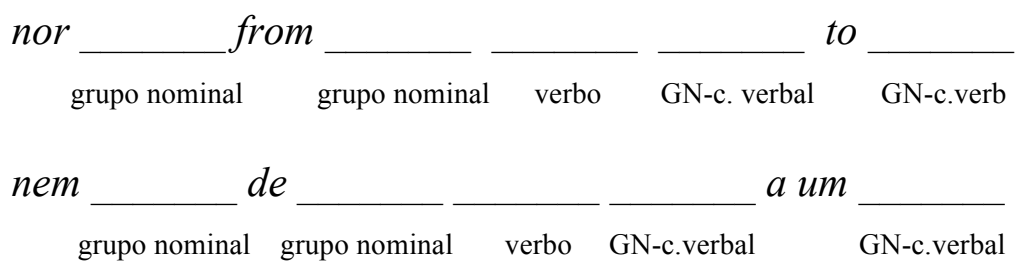

As terminações -ed, em inglês, e -ra, em português, indicam a possível presença de um verbo no terceiro espaço em branco. Bellow significa "bramir", "mugir", e bellows significa "fole". Com bellowsed, temos um verbo inventado a partir de um substantivo, que dá idéia de sopro e também do reavivar de uma chama, trazida pelo fole.

Começam agora as referências religiosas. Mishe mishe foram as palavras, explica Augusto de Campos, que a deusa da Irlanda, Brígida, disse ao ser batizada, e que significam "eu sou, eu sou" em irlandês. Tauf tauf remete ao verbo alemão "taufen", "batizar". Thuartpeatrick é um trocadilho feito sobre um outro, que Joyce afirma ter sido o fundamento da Igreja Católica ("thou art Peter", "tu és Pedro e sobre esta pedra...") e São Patrício, padroeiro da Irlanda e responsável pela sua cristianização. Em tuéspatruísquio, a escolha do tradutor, podemos perceber ecos do "Tu és Pedro", e também de "Patrício". Talvez o tradutor tenha desejado deformar mais a palavra, evocando outras virtuais associações. "Uísque" e "Pátria" são possibilidades.

No texto em inglês, -voice aparece "grudada" com o artigo, procedimento seguido pelo tradutor ( $a v o z$, que traz, ainda, uma homofonia com "avós", reforçando a oposição velho/novo. O mesmo acontece com afire, umachama. No contexto do tema do batismo, trazido por mishe mishe, tauftauf, São Patrício, a deusa Brígida, bellowsed nos remete então ao sopro divino, e talvez à chama do Espírito Santo. Na associação com o batismo, o tema da nomeação "tu és Pedro".

Mas embora os termos pareçam estar centrados ao redor do batismo e da nomeação, a frase parece ter algo que excede uma estrutura sintática que poderíamos esperar. Para que tudo se encaixasse perfeita- 
mente, bellowsed deveria ser um verbo bitransitivo, sendo o objeto direto mishe mishe, e o objeto indireto tauftauf thuartpeatrick. Mas se soubermos a que essas formações estranhas se referem, sintaticamente a frase fica com algo a mais. Seria de esperar que a tal voz dissesse ou mishe mishe ou tauftauf ou thuartpeatrick a alguém. Joyce "repete" as variantes de uma frase performativa ligada à nomeação e ao batismo e as coloca em lugares onde esperaríamos termos que indicassem pessoas. A frase fica truncada, opaca, de difícil entendimento.

A opção do tradutor foi manter exatamente a mesma estrutura sintática, deixando que a falta e o excesso atuem nesse jogo de nomes e nomeações em várias línguas. Aqui, a tradução não "acomoda" a sintaxe estranha para possibilitar uma interpretação. Por outro lado, segue a estrutura sintática, produzindo também em português uma frase truncada e opaca. Mas o reflexo da estrutura sintática só foi possível aí porque a oração é curta. Quando a falta e/ou o excesso jogam numa sequência mais longa, a "acomodação" da sintaxe se faz necessária, como veremos um pouco adiante:

not yet, though venisoon after, had a kidscad buttended a bland old isaac: not yet, though all's fair in vanessy, were sosie sesthers wroth with twone nathandjoe.

nem ainda embora logo mais veniesse, tinha um novelho esaurido um velho e alquebrando isaac: nem ainda, embora tudo seja feério em Vanessidade, tinham as sesters sósias se enrutecido com o uníduo nathandjoe.

Esse trecho, embora não seja de fácil interpretação, tem uma sintaxe mais estruturada, o que permite ao tradutor maior liberdade para criar em português uma estrutura diferente, que se distancia da do texto em inglês, mas consegue reproduzir vários dos efeitos de criação de sentido do original. Aqui, a sintaxe do texto em português não está tão "colada" no inglês como no trecho anterior.

Venisoon after, como já foi observado, ecoa "very soon after" ("logo depois"), mas também é uma brincadeira com venison, "carne de cervo". ${ }^{17}$ Também ecoa "Vanessa", pseudônimo de uma das namoradas secretas de Swift. A sequência not yet, though venisoon after, fica bastante expressiva na tradução de Campos: nem ainda, embora logo mais veniesse, sendo que a última palavra mantém o efeito sonoro que permite as associações no original ("venison", "Vanessa") além de ecoar "viesse". Vemos então que o que em inglês é uma expressão adverbial de tempo aparece em português como um verbo, em virtude da terminação -sse.

\footnotetext{
${ }^{17}$ Augusto de Campos não cita nada a respeito dessa associação em seu comentário da tradução. No entanto, ela está presente em vários comentadores. Ver nota a seguir.
} 
Em had a kidscad buttended a bland old isaac, temos a oposição entre o velho e o novo, kid e old. ${ }^{18}$ Augusto de Campos cita a luta entre Esaú e Jacó pela primogenitura de Isac. ${ }^{19}$ Essa associação justifica que o tradutor coloque em cena Esaú, em esaurido. Essa referência não é explícita no original, mas pode-se deduzi-la pela presença do nome Isaac. Campos valeu-se do jogo entre "exaurir" e o nome de "Esaú", na sequência tinha um novelho esaurido um velho e alquebrando Isaac. Aqui, a tradução cria um efeito gerado pela homofonia, trazendo o equívoco e o cruzamento de duas cadeias, como num chiste. Se aceitarmos essa interpretação, segundo a qual o trecho se refere a Isac, Esaú e Jacó, o acréscimo de Esaú parece perfeitamente justificável. O jogo entre o velho e o novo fica bem articulado em novelho. E, se pensarmos no tema dos jovens substituindo os mais velhos, veremos que Esaú também foi de certa forma exaurido de poder quando vendeu sua primogenitura. Não só o velho Isac, mas também Esaú, como irmão mais velho (portanto um novelho) teriam seus lugares tomados por Jacó, o mais novo.

A though all's fair in vanessy, alguns estudiosos atribuem uma alusão a Vanity Fair, de Thackeray, mais uma das incontáveis referências literárias do texto. Vanessy traz de novo a Vanessa de Swift, que agora vem acompanhada de outras personagens bíblicas femininas, que atraíram homens mais velhos (Susana, Ester e Rute sosie sesthers wroth, ver nota 3, acima). ${ }^{20} \mathrm{Na}$ tradução, embora tudo seja feério em Vanessidade faz um jogo entre o nome próprio "Vanessa" e o substantivo "vaidade" (vanity). Tinham as sester sósias se enrutecido com o uníduo nathanjoe também mantém as referências atribuídas ao original.

\footnotetext{
18 Renato Pompeu sugere que "scad" significa "golpe", e portanto que um "kidscad" seria um golpe aplicado por um garoto, donde seria possível depreender mais uma ocorrência do velho sendo substituído pelo novo. Roland McHugh também nos oferece basicamente a mesma informação (McHUGH, 1991, p. 1). Pompeu explica também que Isaac Butt (buttended) foi um líder nacionalista irlandês do século XIX que perdeu a liderança do movimento anticolonialista para Parnell, considerado, pelo menos por um determinado tempo, um herói na luta anticolonialista. Explica também que, na Biblia, Jacó, filho de Isac, era caçador de cervos (daí a justificativa para a interpretação de venisoon) (1988a, p. 24-26).

${ }^{19}$ Esaú e Jacó, filhos de Isac, eram gêmeos que, segundo a Bíblia, lutavam já no ventre materno. Esaú era o primogênito que, quando cresceu, tornou-se perito caçador. Um dia Esaú volta de uma caçada e pede ao irmão que lhe dê a comida que este preparara. Jacó pede então a Esaú que lhe venda o direito da primogenitura. Esaú cede e troca a primogenitura pela comida. Julga que, estando ele constantemente arriscado a morrer por ser caçador, não tem valor a primogenitura. (Gênesis, cap. 25, vers. 27 a 34).

${ }^{20}$ Renato Pompeu não faz a associação com Susana, Ester e Rute. Para ele, sosie sesthers só faz alusão às duas Esteres de Swift, e wroth associa-se a "wrath" ("ira") (1988, p. 15).
} 
Nesse trecho, é fácil perceber as três operações em ação. Temos, em primeiro lugar, um compromisso com os sentidos atribuídos ao texto, como já foi visto. Mas apesar de esse compromisso com o sentido imperar, há momentos em que o tradutor, para reproduzir uma assonância, deixa o sentido de lado: feério se associa a fair pelo som, e não pela significação; em termos da passagem que se dá na tradução, feério guarda semelhanças com feira (remetendo ao título Feira das Vaidades, em português), descompromissando-se com outras acepções do termo fair em inglês. Pode-se supor que o tradutor tenha seguido os seguintes passos para chegar à sequência tudo seja feério em Vanessidade em português.

A partir de all's fair in vanessy, faz-se a associação com a cadeia "All is fair in love and war", um dito popular da língua inglesa, uma espécie de "vale tudo no amor e na guerra". Dessa cadeia, cai o trecho "love and war", que é substituído "provisoriamente" por "vanity", já que fair traz uma outra cadeia, "Vanity Fair". Identificado aquilo a que o trecho alude, o tradutor o teria traduzido para o português, "Feira das Vaidades".

Mas não é "vanity" que aparece no trecho em inglês, mas sim vanessy, que remete à Vanessa de Swift. Cruzam-se então, em inglês, outras duas cadeias. A de "all is fair in vanity" e uma outra que se associa em termos sonoros, "vanity": "Vanessa": "vanessy", que surge como uma formação composta, uma palavra-valise. O tradutor busca, a partir daí, uma sequência que se assemelhe ao título em português, "Feira das Vaidades" e, ao mesmo tempo, inclua "Vanessa". Chega a tudo seja feério em vanessidade. Feério mantém um compromisso de assonância com "feira", obtido primeiramente pela tradução de fair.

Essa tradução primeira, no entanto, precisou optar por uma das possibilidades geradas pela homonímia entre fair/ "justo" e fair/ "feira" que, possibilitou o cruzamento entre as cadeias, na escrita de Joyce, entre "Vanity Fair" e "All is fair in love and war". Assim, pode-se afirmar que, nesse processo tortuoso e complicado, onde operaram simultaneamente sentidos, assonâncias e equívocos (trazendo a homofonia), o equívoco foi domesticado, porque a língua portuguesa não oferece material significante para preservá-lo.

É difícil precisar a estrutura sintática do próximo trecho. Como se poderá ver, é preciso alguma domesticação para que se possa traduzi-lo.

Rot a peck of pa's malt had Jhem or Shen brewed by arclight and rory end to the regginbrow was to be seen ringsome on the aquaface.

Nem um galão de papamalte haviam Jhem ou Shen recebado à arcaluz e auroras antes o barcoíris fora visto circularco sobre a aquaface.

O problema começa logo com Rot. Pode-se interpretá-lo como um "Not" deformado, como fez Augusto de Campos. Como anteriormen- 
te encontramos vários períodos iniciados com negativas, é possível atribuir a esse rot o sentido de uma negação, mesmo porque ele estaria negando o verbo que vem logo em seguida: "Not a peck of pa's malt had Jhem or Shen brewed...". Mas não se pode esquecer que Rot é um verbo inglês, que significa apodrecer. O tradutor, ao fazer sua opção (aliás, não injustificada), encerra o jogo entre rot e not. Mais adiante, um to parece desestruturar a sintaxe do período. Campos o substitui por um antes, acomodando a sintaxe. A tradução de uma frase assim vai, de uma forma ou de outra, estancar o deslizamento sintático. E isso não é uma inabilidade do tradutor, mas uma condição necessária à tradução. É preciso atribuir um sentido e depois traduzi-lo. É como se Campos tivesse feito algumas substituições na sintaxe do texto de Joyce, tornando-a mais fixa e estruturada, da seguinte maneira:

before Not a peck of pa's malt had Jhem or Shen brewed by arclight and rory end
Rot
the regginbrow $\frac{\text { had been }}{\text { was to be }}$ seen ringsome on the aquaface.

Nem um galão de papamalte haviam Jhem ou Shen recebado à arcaluz e auroras antes o barcoiris fora visto circularco sobre a aquaface.

Mas essas não são as únicas acomodações possíveis. Antes de analisarmos uma outra, vejamos o que o trecho traz em termos de referências e sentidos, segundo os estudiosos:

Rot a peck of pa's malt traz o malte do pai ( $p a$ 's malt). Peck pode ser uma medida de volume (de produtos secos, como o malte) e também uma bicada. A única palavra que aparece deformada aqui é rot, que significa "apodrecer", mas que ecoa "not", que seria nossa expectativa, lendo "nenhum peck do malte do pai". Em nem um galão de papamalte, perdese a associação com rot, que nos poderia levar à interpretação de um malte podre. Nessa interpretação, "Nem podre um galão do papamalte ser..." poderia sinalizar para uma solução. Jhem e Shen ${ }^{21}$ são dois dos nomes de um dos filhos de H.C. E., o escritor, "Shem the penman". Arclight, regginbrow e ringsome trazem associações com o arco-íris ("arco de luz", "rainbow" em inglês e "reggenbogen" em alemão, ambas as palavras significando "arco-íris"). Rory, por associação com "roral", evoca "orvalho". Aquaface, que não se altera na tradução, nos lembra "face" e "água". Augusto de Campos, juntamente com alguns estudiosos como Burgess e

\footnotetext{
${ }^{21}$ Há também uma associação com os nomes de dois filhos de Noé, Sem e Cam. O terceiro filho de Noé se chamava Jafet. Ver nota 21, logo abaixo.
} 
Tindall ${ }^{22}$ atribuem para esse trecho uma interpretação ligada a Noé e ao dilúvio. Arc traz ao mesmo tempo o arco e a arca. O arco-íris indica o fim das chuvas e a aliança de Noé com Deus. ${ }^{23}$ A tradução mantém as referências no nível da alusão, como faz o original.

Mas, voltando à estrutura sintática da frase, vejamos que outras "acomodações" seriam possíveis. Ao lado daquela já indicada, que reproduzo aqui:

Not a peck of pa's malt had Jhem or Shen brewed by arclight and rory end

before

Rot

to

the regginbrow had been seen ringsome on the aquaface.

was to be

Poderíamos ter:

Not a peck of pa's malt that Jhem or Shen brewed by arclight and rory end to Rot had

the regginbrow was to be seen ringsome on the aquaface.

Ou ainda, numa acomodação mais forçada, talvez pudéssemos ter:

end to

Rotten, a peck of pa's malt that Jhem or Shen brewed by arclight and rory

Rot had

the regginbrow was to be seen ringsome on the aquaface.

O próximo parágrafo, apesar de conter vários termos estranhos, também apresenta uma sintaxe bastante estruturada, que é seguida de perto pelo texto em português.

\footnotetext{
${ }^{22} \mathrm{Na}$ verdade, todos na esteira do próprio Joyce, que fez uma breve explicação dessa primeira página numa carta à sua protetora, Harriet Weaver.

23 "E Deus disse: eis o sinal da aliança, que faço entre mim e vós, e com todos os animais viventes que estão convosco, por todas as gerações futuras: Porei o meu arco nas nuvens e ele será o sinal da aliança entre mim e a terra" (Gênesis, cap. 8, vers. 12-13). Cessadas as chuvas, as águas recuam e Noé pode descer a terra junto com sua mulher, seus filhos e as esposas de seus filhos. Noé, que era agricultor, passou a cultivar uma vinha. Após a colheita, bebeu vinho e embriagou-se. Bêbado, Noé aparece nu em sua tenda. A reação do primeiro filho que o vê, Cam, é apenas ir contar o fato aos outros dois irmãos. Estes últimos cobrem o pai e evitam olhar sua nudez. Noé, despertando da embriaguez, amaldiçoa Cam pelo que fez, e o transforma em seu escravo. Cam viveu nessa condição por todos os trezentos e cinquenta anos restantes da vida de Noé, que já tinha seiscentos. A nudez de Noé se liga ao exibicionismo de H. C. E., quando vê duas moças urinando no Parque Fênix. Por esse ato, H. C. E. é punido e sofre toda sorte de humilhações, vindo no final a ser redimido por sua mulher Anna Livia.
} 
The

fall (bababadalgharaghtakamminarronnkonnbronntonnerrotuonnthunntrova rrhounawnskawmtoohoohoordenethurnik!) of a once wallstrait oldparr is retaled early in bed and later on life down through all christian minstrelsy.

A

queda

(bababadalgharaghtakamminarronnkonnbronntonnerrotuonnthunntrova rrhounawnskawmtoohoohoordenethurnik!) de um ex venereável negociante é recontada cedo na cama e logo na fama por todos os recantores da cristã idade.

The fall of $a \underset{\text { grupo nominal }}{\text { through all }}$ is early in bed and later on life down
grupo nominal

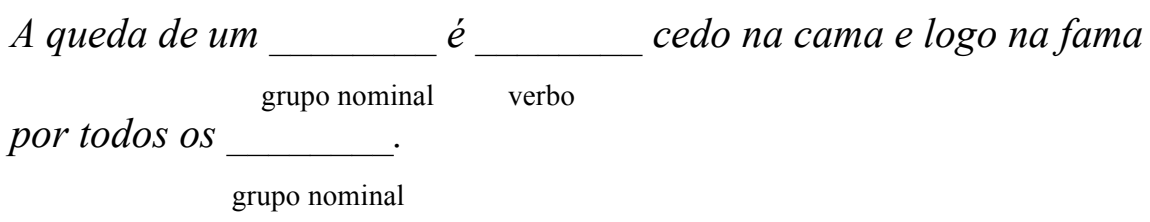

Este último parágrafo, como o próprio início anuncia, trata da queda, ou das quedas. A assustadora palavra de cem letras é uma espécie de trovão multilíngue, ${ }^{24}$ anunciando o fim de uma era viconiana e o início de outra. A queda refere-se à queda de Adão, da bolsa de Nova York (wallstrait ecoando "Wall Street"), de Humpty Dumpty, o homem-ovo de Alice no País dos Espelhos, de Lewis Carroll. ${ }^{25}$ Prosseguindo:

\footnotetext{
${ }^{24}$ Como explica Tindall, "trovões" desse tipo se repetem mais nove vezes ao longo do livro, e este, em especial, é composto de palavras que denotam ruído e defecação. Konnbronn, por exemplo, faz alusão ao General Pierre Cambronne e uma palavra que ele repetia, "merde" (TINDALL, 1969, p. 32). Renato Pompeu indica que gharagh seria o hindustâni "karak", que significa "trovão". Kamminarron seria originado do termo japonês para trovão, "kaminari". Também seriam reconhecíveis outros termos para "trovão" como o grego "brontao", o francês "tonnerre", o italiano "tuono", o sueco "aska", o dinamarquês "tordenen". Todos esses termos estariam, segundo Pompeu, "retrabalhados" no texto (1988b, p. 22-24).

${ }^{25}$ Campos nos fornece essa referência literária, mas Humpty-Dumpty faz parte também de uma quadrinha infantil. É um homem em forma de ovo, ou um ovo personificado, que cai de um muro e se espatifa no chão. "Humpty Dumpty sat on a wall/Humpty Dumpty had a great fall./All the King's horses and all the King's men/ Couldn't put Humpty together again". O pedreiro Tim Finnegan também cai de uma escada quando está construindo um muro. De acordo com a lenda, o gigante Finn MacCool, quando cai, também se espatifa no chão, e os pedaços de seu corpo se espalham por Dublin. Sua cabeça corresponde à colina de Howth, seus pés estão perto do bar de Earwicker. (BURGESS, 1971, p. 217).
} 
The great fall of the offwall entailed at such short notice the pftjschute of Finnegan, erse solid man, that the humptyhillhead of humself prumptly sends an unquiring one well to the west in quest of his tumptytumtoes: and their upturnpikepointandplace is at the knock out in the park where oranges have been laid to rust upon the green since devlinsfirst loved livvy.

A grande queda do ovalto do muro acarretou em tão pouco lapso o pftschute de Finnegan, outrora sólido ovarão, que a humptyhaltesta dele prumptamente manda uma testemunha para oeste à cata de suas humptytumtunhas: e o retrospicopontoepouso delas repausa em pés no parque onde oranjos mofam sobre o verde desde que o primoamor ao diablin levou lívia.

Em termos da estrutura sintática, temos:

The great fall $[\ldots]$ entailed at such short notice the

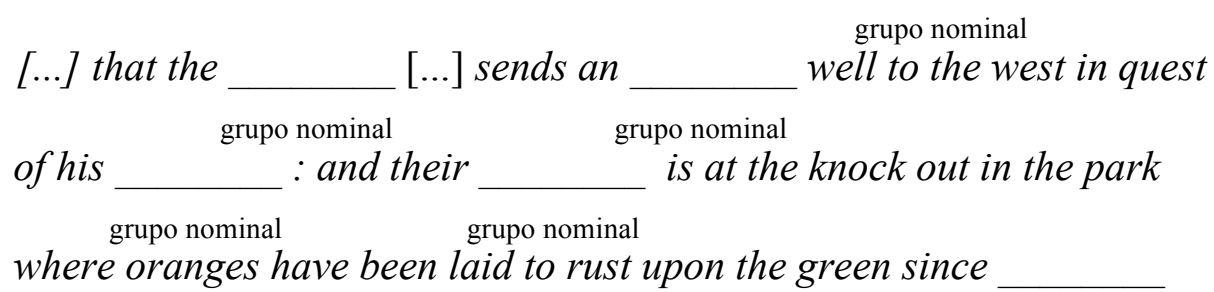

loved livvy.

grupo nominal

Que, na tradução, permanece num paralelo quase perfeito:

A grande queda [...] acarretou em tão pouco lapso o
[...] que a _ _...] manda uma testemunha para oeste à cata
grupo nominal

de suas $\underset{\text { grupo nominal }}{ }: e o_{\text {grupo nominal }}$ repausa em pés no parque

onde oranjos mofam sobre o verde desde que o

ao diablin levou lívia.

grupo nominal

Orangemen, segundo Campos, são invasores da Irlanda. Joyce constrói as palavras de forma a sugerir a divisão das partes do corpo do gigante e de Humpty Dumpty. Temos então humptyhillhead (a cabeça do 
gigante que se transforma da colina de Howth, juntamente com Humpty Dumpty) e tumptytumtoes (ecoando "Dumpty" e "toes", "dedos dos pés"). A tradução segue o mesmo procedimento, desmembrando as palavras, combinando "Humpty" com "testa" (humptyhaltesta) e "Tumpty" e "unhas" (tumptytumtunhas). Se em termos sintáticos a tradução não é muito complicada, é notável a "ginástica com a palavra" ${ }^{26}$ empreendida aqui. As alusões e referências são mantidas quase em sua totalidade, mas não de uma forma "colada" ao texto original, e sim num eficiente sistema de compensações. Se não há, em português, uma palavra que ecoe "Wall Street", temos negaciante. As referências ao homem-ovo, HumptyDumpty, são estendidas em palavras-valise como ovarão, e ovalto do muro. Há também outras formações interessantes, como ex venereável, ou recantores.

As inúmeras aliterações em the humptyhillhead of humself prumptly sends an unquiring one well to the west in quest of his tumptytumtoes são de certa forma recuperadas em a humptyhalltesta dele prumptamente manda uma testemunha para oeste à cata de suas tumptytumtunhas. Não com os mesmos fonemas, mas mantendo um compromisso com a assonância que o texto em inglês nos traz. Mais uma vez é possível perceber que, quando a sintaxe tem uma estrutura mais bem-delineada, o tradutor pode empreender sua ginástica verbal com mais liberdade, pois o sentido antecipado por essa estrutura sintática, juntamente com as interpretações sugeridas pelos estudiosos, pode ser garantido de alguma outra forma, de acordo com o que nos oferece o material significante da língua portuguesa.

\section{Conclusão}

Como se tentou demonstrar, a escrita de Joyce é difícil, intrincada, exótica, mas não impossível de ler. Para empreender essa leitura, o leitor precisa se dedicar a um estudo panorâmico de várias culturas, línguas, povos e crenças, o que conferirá a sua leitura uma consistência, um arcabouço que lhe permita um mínimo reconhecimento. Também será necessário que o leitor se entregue a jogos simbólicos fora da significação comum, determinada por nosso conhecimento das cadeias significantes da língua. Sua escuta deverá, a todo momento, estar aberta ao equívoco, à homofonia, ao cruzamento inusitado dessas cadeias.

\footnotetext{
26 "Traduzir James Joyce, espcialmente fragmentos de Finnegans Wake, é uma ginástica com a palavra: um trabalho de perfeccionismo". É assim que Haroldo de Campos define seu trabalho em Panaroma do Finnegans Wake (CAMPOS e CAMPOS, 1971, p. 21).
} 
Se a leitura do texto joyciano não é radicalmente impossível, embora imponha um certo distanciamento do que, em termos gerais, concebemos ser a leitura e a interpretação, também sua tradução não é radicalmente impossível. Em determinados pontos, podem-se identificar dificuldades que são semelhantes às encontradas na tradução de textos poéticos, em que a homofonia, trazendo o equívoco, impede que o mesmo efeito seja produzido no mesmo lugar, ou com o mesmo material significante. Mas é possível, como sugere Nestrovski, criar efeitos de mesmo valor em outros pontos do texto.

A tradução do texto de Joyce se torna impossível quando a sintaxe não sustenta a articulação dos sentidos, deslizando e deixando o leitor/tradutor à deriva. A presença ou a ausência, às vezes de uma pequena partícula, outras vezes de cadeias maiores, não só quebram a expectativa do leitor, mas não lhe oferecem pontos de ancoragem. Se traduzir é escrever tendo como base a significação, e se a significação é um efeito da articulação de cadeias significantes, é indispensável que o tradutor disponha de uma estrutura sintática na qual possa se apoiar. Nos pontos em que surgem esses deslizamentos, o tradutor precisa de certa forma "congelar" o texto, retirando ou acrescentando termos, acomodando a sintaxe para que a partir dela possa depreender uma significação. Esse trabalho de acomodação da sintaxe, que em textos "normais" poucas vezes se faz necessário, é uma exigência constantemente imposta pelo texto de Finnegans Wake.

Lenita Rimoli Esteves lenitaesteves@usp.br Universidade de São Paulo 


\section{Referências bibliográficas}

ALLOUCH, J. Letra a letra (trad. Dulce Duque Estrada). Rio de Janeiro: Campo Matêmico, 1994.

BURGESS, A. A shorter Finnegans Wake, 2 ed. Londres, Faber \& Faber, 1966.

Homem Comum Enfim - Uma introdução a James Joyce para o leitor comum. (trad. José Antonio Arantes). São Paulo: Companhia das Letras, 1971.

CAMPBELL, J.; ROBINSON, H. M. Campbell. A Skeleton Key to Finnegans Wake. Harcourt Brace, 1944.

CAMPBELL, J. e ROBINSON, H. M. Introdução a um Assunto Estranho (trad. Augusto de Campos). In: CAMPOS, A.; CAMPOS, H. Panaroma do Finnegans Wake. São Paulo: Companhia das Letras, 1971.

CAMPOS, A.; CAMPOS, H. Panaroma do Finnegans Wake. São Paulo: Perspectiva, 1971.

DEANE, S. Introdução. In: JOYCE, J, Finnegans Wake. Penguin Books, 1992.

DERRIDA, J. Duas Palavras por Joyce (trad. Regina Crisse de Agostinho). In: NESTROVSKI, A. (org.): riverrun - Ensaios sobre James Joyce. Rio de Janeiro: Imago, 1992.

DIXON, V. A litter to Mr. James Joyce. In: BECKETT, S. Our Exagmination round his factification for incamination of Work in Progress. Londres: Faber \& Faber, 1961.

FREUD, S. El chiste y su relación con lo inconsciente. (1905) Obras Completas, vol. VII Amorrortu, Argentina.

de 1949).

Finnegans Wake. Londres: Faber \& Faber, 1939 (reimpressão

MAGALANER, M. e KAIN, R. M. Joyce - The man, the work, the reputation. Nova York: New York University Press, 1956 
McCALMON, R. Mr. Joyce Directs an Irish Word Ballet. in: In: BECKETT, S. Our Exagmination round his factification for incamination of Work in Progress. Londres: Faber \& Faber, 1961.

McHUGH, R. Annotations to Finnegans Wake. Baltimore e Londres: The Johns Hopkins University Press, 1991.

NESTROVSKI, A. Mercius (de seu mesmo): notes on a Brazilian translation of Finnegans Wake. In NESTROVSKI, A. James Joyce Quarterly, vol. 27, no. 3, Primavera de 1990.

POMPEU, R. Tristão e Isolda Segundo James Joyce. In: Cult - Revista Brasileira de Literatura, no. 6, jan. 1988a.

Um Trovão Plurilíngüe. In: Cult - Revista Brasileira de Literatura, no. 9, abril 1998b.

TINDALL, W. Y., A Reader's Guide do Finnegans Wake. Londres: Thames and Hudson, 1969.

VELOSO, C. Não Verás Paris como Este. In: RODRIGUES, A. M. (org.) Antologia da literatura brasileira, vol. II. São Paulo: Marco, 1979.

VIZIOLI, P. James Joyce e sua obra literária. São Paulo: E.P.U., 1991. 